NBER WORKING PAPER SERIES

\title{
STRUCTURAL CHANGE, FUNDAMENTALS AND GROWTH: A FRAMEWORK AND CASE STUDIES
}

\author{
Margaret McMillan \\ Dani Rodrik \\ Claudia Sepulveda \\ Working Paper 23378 \\ http://www.nber.org/papers/w23378 \\ NATIONAL BUREAU OF ECONOMIC RESEARCH \\ 1050 Massachusetts Avenue \\ Cambridge, MA 02138 \\ May 2017
}

This project was funded by the World Bank Knowledge for Change Program. Chapter authors participated in a workshop at the World Bank, co-hosted by the International Food Policy Research Institute (IFPRI) in 2012. We would like to thank all those who participated as discussants and observers; their comments were extremely helpful in shaping the direction of this volume. We are also grateful for the assistance of the Publication Review Committee at IFPRI and the comments received from anonymous reviewers. The authors acknowledge the support of the CGIAR Research Program on Policies, Institutions, and Markets (PIM) led by IFPRI. Finally, we would like to thank Xinshen Diao and Ann Harrison for their encouragement and support throughout the process. The views expressed herein are those of the authors and do not necessarily reflect the views of the National Bureau of Economic Research.

NBER working papers are circulated for discussion and comment purposes. They have not been peer-reviewed or been subject to the review by the NBER Board of Directors that accompanies official NBER publications.

(C) 2017 by Margaret McMillan, Dani Rodrik, and Claudia Sepulveda. All rights reserved. Short sections of text, not to exceed two paragraphs, may be quoted without explicit permission provided that full credit, including $\odot$ notice, is given to the source. 
Structural Change, Fundamentals and Growth: A Framework and Case Studies

Margaret McMillan, Dani Rodrik, and Claudia Sepulveda

NBER Working Paper No. 23378

May 2017

JEL No. O11

\begin{abstract}
Developing countries made considerable gains during the first decade of the 21 st century. Their economies grew at unprecedented rates, resulting in large reductions in extreme poverty and a significant expansion of the middle class. But more recently that progress has slowed with an economic environment of lackluster global trade, not enough jobs coupled with skills mismatches, continued globalization and technological change, greater income inequality, unprecedented population aging in richer countries, and youth bulges in the poorer ones. This essay examines how seven key countries fared from 1990-2010 in their development quest. The sample includes seven developing countries_-Botswana, Ghana, Nigeria, Zambia, India, Vietnam and Brazil —all of which experienced rapid growth in recent years, but for different reasons. The patterns of growth are analyzed in each of these countries using a unifying framework which draws a distinction between the "structural transformation" and "fundamentals" challenge in growth. Out of these seven countries, the traditional path to rapid growth of export oriented industrialization only played a significant role in Vietnam.

Margaret McMillan

Tufts University

Department of Economics

114a Braker Hall

Medford, MA 02155

and International Food Policy Research Institute

and also NBER

margaret.mcmillan@tufts.edu

Dani Rodrik

John F. Kennedy School of Government

Harvard University

79 J.F. Kennedy Street

Cambridge, MA 02138

and NBER

dani_rodrik@harvard.edu

Claudia Sepulveda

The World Bank

1818 H St. NW

Washington, DC 20433

csepulveda@worldbank.org
\end{abstract}




\section{Introduction}

The first decade of the 21 st century was extraordinarily good for developing countries and their mostly poor citizens. Their economies expanded at unprecedented rates, resulting in both a large reduction in extreme poverty and a significant expansion of the middle class. In fact, their growth rates were an average 4 percentage points faster than those of the advanced countriesversus only 1.3 percentage points in the 1990s (Figure O.1a). This growth was led by the efforts of China, India, and a small number of other Asian countries, and assisted by the weaker economic performance of the rich countries. Latin America and Africa resumed growth as well, catching up with - and often surpassing — the growth rates they experienced during the 1950s and 1960s. As a result, the developing countries moved more quickly to close the income gap with the advanced countries (Figure O.1b), a process known as economic convergence. More recently, however, that process has slowed down — reflecting a narrowing of the advanced and developing country growth rate differentials since 2010 - making it unlikely that poorer countries will be able to close the development gap with richer countries any- time soon.

What are the growth prospects for developing countries? Two traditions for examining and explaining growth exist side by side within economics. The first has its roots in development economics and is based on the dual-economy approach (initially formalized by Lewis 1954 and expanded upon by Ranis and Fei 1961). It draws a sharp distinction between the traditional (agri culture) and modern (industry) sectors of the economy, and it assumes that different economic logics are at work within them-and therefore the two sectors cannot be lumped together. Accumulation, innovation, and productivity growth all take place in the modern sector-often in unexplained ways - while the traditional sector remains technologically backward and stagnant. Thus, economywide growth depends largely on the rate at which resources - principally laborcan migrate from the traditional to the modern sector. 
FIGURE O.1a Withadvancedanddeveloping country growthratedifferentialsnarrowing in the 2000 s...

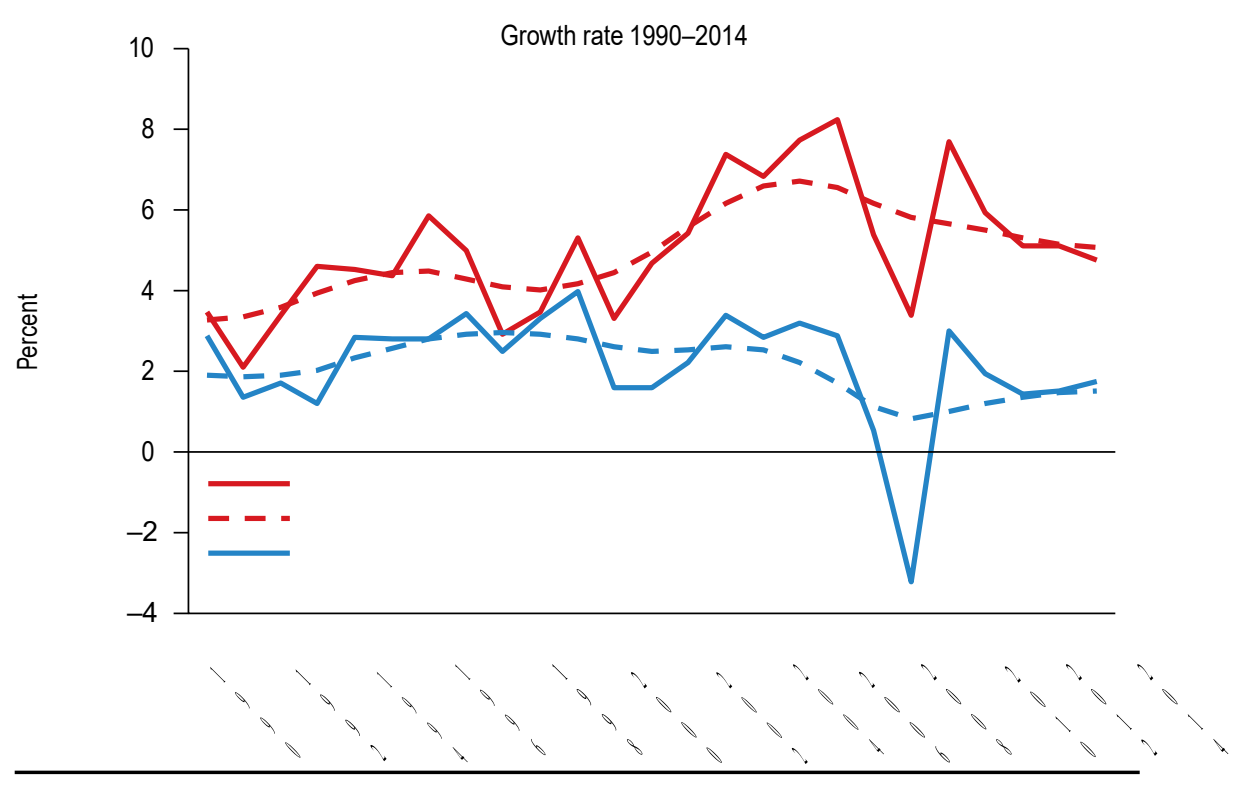

Source:World DevelopmentIndicators database(World Bank, variousyears).

FIGURE 0.1b ... the income gap has been closing more rapidly than in the 1990s

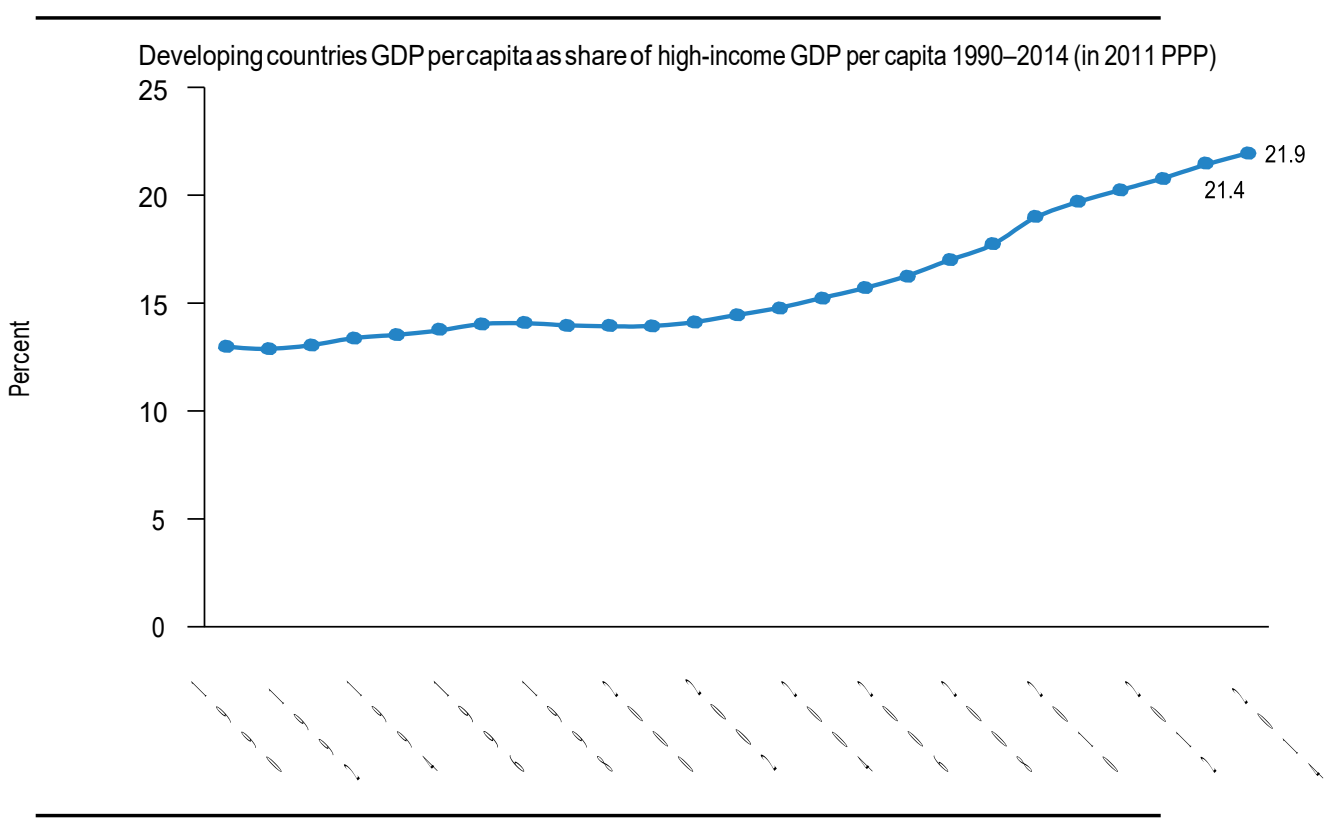

Source: WorldDevelopmentIndicators database (WorldBank, various years).

Note: The gross domestic product (GDP) trend was calculated using a Hodrick-Prescott filter with smoothing parameter equal to 6.25; PPP = purchasing power parity. 
The second tradition has its roots in macroeconomics, and derives from the neoclassical growth model of Solow (1956). It eschews such distinctions and presumes different types of economic activity are structurally similar enough to be aggregated into a single representative sector. In neoclassical models, growth depends on the incentives to save, accumulate physical and human capital, and (in subsequent variants that endogenize technological change) innovate by developing new products and processes (Grossman and Helpman 1991; Aghion and Howitt 1992).

These traditions offer complementary perspectives on economic growth. One way to combine their insights is to think of the neoclassical model as essentially focusing on the growth process within modern sectors, while the dual-economy model focuses on relationships and flows among sectors. As such, each perspective provides a distinct reason why growth in the lagging countries should be not just feasible, but also easy and rapid. In the dual- economy world, growth is just a matter of moving traditional farmers into modern industries in urban areas where productivity is on a positive trajectory. In the neoclassical world, physical and human capital levels in developing countries are low, and thus returns to accumulation should be high. Either way, economic convergence with rich nations should be the norm rather than the exception.

As it turns out, however, those predictions have not been borne out.

Nevertheless, their failure informs us about the obstacles that need to be over- come if economic development is to happen. Using these two sets of models to guide us, we can identify two broad development challenges:

- The "structural transformation" challenge: How to ensure that resources flow rapidly to the modern economic activities that operate at higher levels of economic productivity.

- The "fundamentals" challenge: How to accumulate the skills and broad institutional capabilities needed to generate sustained productivity growth, not just in a few modern industrial sectors but also across the entire range of services and other nontradable activities. There is considerable debate about whether it is primarily the quality of institutions (governance, rules of law, and the business environment) or the level of human capital (education, skills, and training) that drives long-run levels of income (see Acemoglu, Johnson, and Robinson 2001 
versus Glaeser et al. 2004). But for our purposes, we can just lump them under the rubric of "fundamentals."

The critical question is the relationship between these two challenges, especially in Africa, which, until recently, has been largely absent from any work on structural change (Box O.1). A major reason for this absence has been largely unreliable or nonexistent economic data for most African countries. A deeper reason is poverty itself. Until recently, few African countries have enjoyed the sustained economic growth needed to trace the patterns of structural transformation achieved in earlier decades elsewhere. However, since the beginning of this century, African countries have grown at an unprecedented pace and in unusual ways, making them especially interesting for such research.

This book speaks directly to our lack of information about structural change and growth in developing countries. It includes four African countries-

Botswana, Ghana, Nigeria, and Zambia — all of which have experienced rapid growth in recent years, but for different reasons. They are also interesting because it does not appear that the process of structural change in any of these countries is following the standard patterns that we are familiar with from the historical literature or from widely used models of structural

change. These case studies may thus shed light on both the processes that are unfolding at present and some of the barriers that remain. We also include two fast-growing Asian countries that appear to be following different paths: India and Vietnam. Finally, we include Brazil because of its position as a "postindustrial" developing country.

The authors of these chapters try to answer how much of the growth in labor productivity during given time periods can be attributed to the "within- sector" versus the "structural change" component, paying particular attention to the structural transformation challenge (drawing on the methodology in McMillan and Rodrik 2011). While the starting year for each country differs depending on data availability, all of the studies cover the period 1990-2010. Moreover, the authors painstakingly piece together data to paint a detailed account of structural change for subperiods and sectors. 
From these chapters, we learn that the experience with structural change has been quite diverse around the world. In particular:

- Structural change played only a tiny role in the recent growth performance of the middleincome countries of Brazil and Botswana, although it did play an important role in launching them into middle-income status.

- Structural change contributed significantly to growth in Vietnam and Ghana over the past two decades, although their experiences have been quite different — with Vietnam undergoing much more industrialization than Ghana, where the formal manufacturing sector is still relatively small.

- Structural change contributed to growth in India, Nigeria, and Zambia, but it is not the kind of structural change that China and Vietnam enjoyed. Rather, the three countries have seen a less rapid decline in the employment share of low-productivity agriculture, exacerbated by the lack of a boom in labor-intensive manufacturing for export.

In short, the policy requirements of rapid structural change do not seem to align neatly with conventional recommendations of the "fundamentals" type. Despite significant improvements in policy regimes in Africa - macroeconomic stabilization, external opening, democratization - the rate and direction of structural transformation have been disappointing in this region. And in Latin America, although privatization and liberalization may have contributed to within-sector productivity growth, they seem to have done so at the expense of economywide productivity. In countries with significant unexploited potential for structural change, there are large payoffs for taking imaginative shortcuts (such as investment zones or competitive currencies) that target the development of new industries directly. In other cases, policies must remain focused on long-run fundamentals - institutions and human capital. 


\section{Box O.1 An eclectic spin on the two traditions}

From a theoretical perspective, within-sector productivity growth and structural change go hand in hand, but there is disagreement as to where the process of growth originates. For example, Schultz (1953) argued that in a closed-economy setting, advances in agricultural productivity are a pre- condition for growth. This view featured prominently in several later pieces, including work by Johnston and Mellor (1961), Johnston and Kilby (1975), and Timmer (1988). More recently, the role of agriculture has featured prominently in work by noneconomists, such as Jared Diamond (1997).

In stark contrast to Schultz (1953), Sir Arthur Lewis (1954) argued that the low marginal productivity of farm labor would persist until nonfarm employment expanded enough to absorb rural population growth. Moreover, industrialization could mechanically raise agricultural productivity by reducing the size of the labor force in agriculture without affecting output. Subsequent work also challenged the link between agricultural productivity growth and structural change by using open- rather than closed-economy models (for example, Mokyr 1976; Field 1978; Wright 1979; Matsuyama 1992). Rather than focusing on international trade, a third strand of the literature began to emphasize the "special" properties of industry — such as increasing returns, learning by doing, and coordination failures — and called for a "big push" type of industrial policy (for example, Murphy, Shleifer, and Vishny 1989).

More recent work on structural change has typically focused on documenting the stylized facts of structural change, estimating the contribution of structural change to economywide productivity growth, and developing multi-sector growth models consistent with the stylized facts of structural change. This work was recently reviewed in an excellent and extensive piece on growth and structural change by Herrendorf, Rogerson, and Valentinyi (2013).

From the perspective of our book, the most important conclusion they reach is probably the fact that economists have a substantial amount of dataregarding the process of structural transformation in today's advanced economies, but we know little about this process in today's developing economies. To what extent are they following different paths from today's developed economies? And if so, what factors give rise to these differences? Specifically, Herrendorf, Rogerson, and Valentinyi (2013) call for more quantitative studies on structural transformation in today's poor economies - a topic that our book tries to shed light on. They also emphasize the importance of two issues that they did not examine in their review piece. The first is human capital and its role in determining both within- and across-sector productivity growth. The second is market failures and the role for government — notably, the extent to which externalities, public goods, market power, or other factors associated with inefficient equilibrium outcomes - shape the process of structural change. 


\section{A Unifying Framework}

To place these results in perspective, we begin this overview with an overall unifying framework for thinking about growth (drawing on Rodrik 2013a). We drew above a distinction between the "structural transformation" and "fundamentals" challenges in growth - the first focusing on moving resources into modern industries, and the second on developing broad capabilities. At first sight, these two challenges may seem one and the same, too closely linked to be separable. Much of the development literature operates on the assumption that policy that is good on one front is also good on the other. For example, investing in human capital and improving the legal regime should be good for boosting overall productivity, as well as promoting industrial expansion.

Deregulating industrial restrictions and international trade should be good for developing the economy as a whole, as well as fostering entry into new economic activities. What is desirable policy for growth need not differ based on whether we look at growth from the perspective of facilitating structural transformation or building fundamentals.

While there is substantial overlap between the two sets of policies, it is also clear that the two challenges have somewhat different strategic implications. In practice, it may be far easier to promote industrialization directly, by subsidizing industry in diverse ways or removing specific obstacles to it, than to promote it indirectly by making broad investments in human capital and institutions and hoping that these will trickle down to investment incentives in industry. It is possible to have rapid structural transformation (in other words, industrialization) without significant improvements in fundamentals. East Asia is the premier example of this strategy. In China, governance and human capital have lagged significantly behind the country's manufacturing prowess. Vietnam is a similar case, following on China's footsteps with some lag.

It is also possible to invest significantly in fundamentals without reaping much reward in terms of structural transformation. Since the early 1990s, Latin America has considerably improved its governance and macroeconomic fundamentals, yet structural change in the region has been, if anything, growth reducing. Manufacturing and some other modern sectors have lost employment to lower-productivity services and informal activities (McMillan and Rodrik 2011). 
We can visualize these possibilities in Figure O.2, which depicts a typology of growth patterns and outcomes. It shows that structural transformation can fuel rapid growth on its own, but if it is not backed up by fundamentals, growth peters out and remains episodic (quadrant 2). On the other hand, the accumulation of fundamentals, which requires costly, time-consuming, and complementary investments across the entire economy, only produces steady but slow growth if it is not backed up by structural change (quadrant 3). The bottom line is that, ultimately, sustained growth and convergence require both processes (quadrant 4). Even in the best of all worlds, structural transformation will eventually run its course and industrialization will reach its limits.

FIGURE 0.2 A typology of growth patterns and outcomes

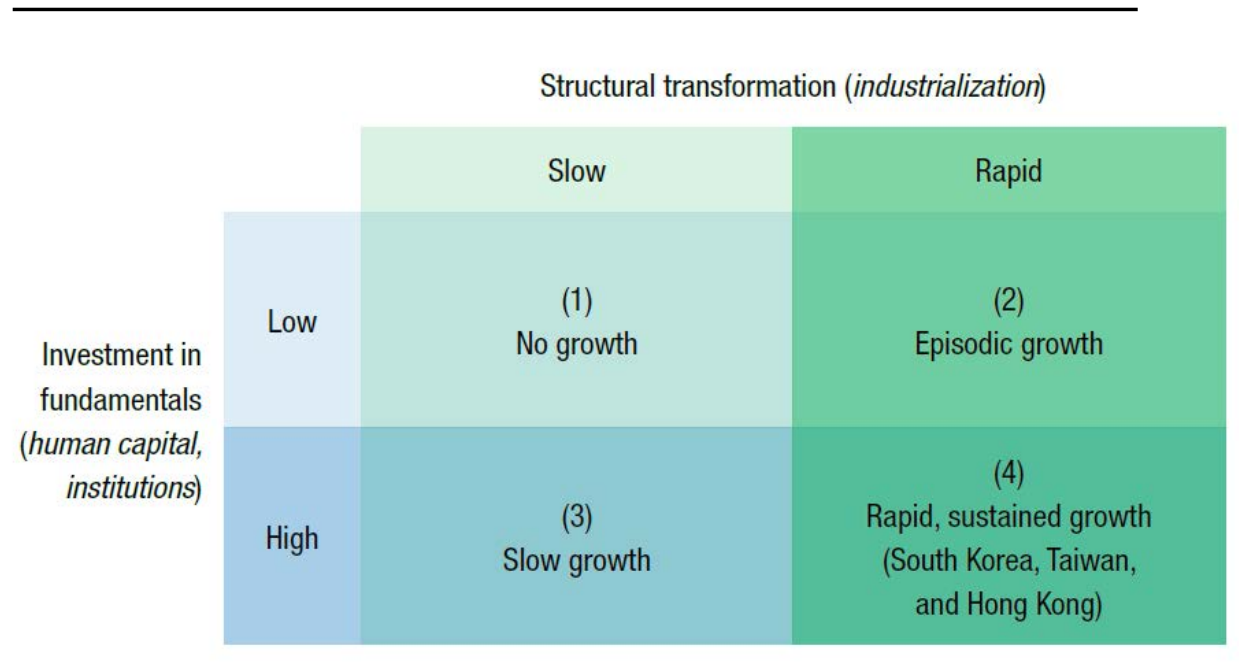

Source: authors. 
From that point on, growth must depend on the steady accumulation of fundamentals emphasized by neoclassical growth theory. Long-term successes, such as Britain, Germany, and the United States, have all gone through these phases, as have more recent examples, such as Japan, South Korea, and Taiwan, China. If doubts remain about China's economic future, it is because so much of the country's institutional transformation, particularly with respect to political institutions, still remains ahead of it.

This typology helps clarify one of the puzzling aspects of cross-national data: institutional quality and human capital are both highly correlated with income levels, yet improvements in institutions and human capital are not a reliable predictor of economic growth. It suggests that this empirical finding is not a contradiction. Only countries that steadily enhance their fundamental capabilities eventually become rich. But investment in fundamentals is not the quickest or easiest way of getting there, at least during the early stages of development. Early on, it is rapid industrialization that fuels growth, and this requires policies that may differ considerably from conventional fundamentals. Countries that rely exclusively on building up broad-based capabilities are rewarded with modest growth, and may in fact be diverted from those policies as a result (Rodrik 2013a).

We will use this typology to interpret the experiences of our country examples. None of them can be said to have made it definitively to the nirvana of quadrant (4). Botswana has high fundamentals but limited structural change, while Vietnam has relatively rapid structural change but relatively low fundamentals. Our other African examples (Ghana, Nigeria, and Zambia) typically have had episodic growth-promoting structural change at best, moving back and forth between quadrants (1) and (2), although Ghana has recently moved into quadrant (3). Brazil has moved from quadrant (2) to quadrant (3), with greatly improved fundamentals but much weaker growth underpinned by slow structural change. India meanwhile has not experienced the kind of structural change that import-substituting countries (such as Brazil in the 1950s-1970s) or the East Asian exporters (such as Vietnam) have gone through, so its growth prospects remain brittle. 


\section{Country Studies: Methodology}

In an effort to retain consistency across country studies, all of the country chapters use the same methodology as McMillan and Rodrik (2011). This approach is not intended to resolve questions about causality; rather, it is intended to lay out a set of facts that we hope will help policy makers better understand their economies and allow future researchers to develop better theories of growth and structural change.

The decomposition used in our paper follows Haltiwanger (1997) and Foster, Haltiwanger, and Krizan (2001), who used this decomposition to explore the contributions of the reallocation of activity across plants and plant productivity growth to overall productivity growth in the US manufacturing sector. Instead, we use this decomposition to establish the contributions of the reallocation of activity across broad sectors of the economy and sectoral productivity growth to economywide productivity growth.

There is no doubt that studying productivity at the sector level necessarily masks the underlying heterogeneity of productivity within sectors. However, focusing solely on heterogeneity within one particular sector ignores the economywide implications of sectorspecific changes in productivity. For example, numerous studies have shown that intensified import competition has forced manufacturing industries across the globe to become more efficient by rationalizing their operations. Typically, the least productive firms have exited manufacturing, while the remaining firms have shed "excess labor." It is evident that the top tier of firms has closed the gap with the technology frontier in Latin America and Africa, no less than in East Asia.

However, the question left unanswered by these studies concerns what happens to the workers who are thereby displaced. In economies that do not exhibit large intersectoral productivity gaps or high and persistent unemployment, labor displacement would not have important implications for economywide productivity. In developing economies, on the other hand, the prospect that the displaced workers would end up in even lower-productivity activities (services, informality) cannot be ruled out. That is, indeed, what seems to have typically happened in Latin America. An important advantage of the broad, economywide approach taken in this volume is that the 
authors are able to capture changes in intersectoral allocative efficiency, as well as improvements in within-industry productivity.

In this framework, total labor productivity is given by:

$$
P_{t}=\sum_{i=1}^{n} \theta_{\mathrm{i}, \mathrm{t}} P_{i, t}
$$

where $P_{t}$ is total labor productivity in year $t, \theta_{i, t}$ denotes the proportion of total labor employed in sector $i$ at time $t$, and $p_{i, t}$ denotes labor productivity in sector $i$ at time $t$; where $i=1, \ldots, 9$. Then, the change in total labor productivity between $t$ and $t-k(\Delta P t)$ can be written as:

$$
\Delta P_{t}=\sum_{i=1}^{n} \theta_{\mathrm{i}, \mathrm{t}-\mathrm{k}} \Delta P_{i, t}+\sum_{i=1}^{n} \Delta P_{i, t-k}+\sum_{i=1}^{n} \Delta \theta_{i, t} \Delta P_{i, t}
$$

Whereas the first term on the right-hand side (RHS) captures within-sector productivity changes, the second term on the RHS captures between-sector productivity changes, and the third term on the RHS captures cross-sector productivity changes. In essence, the cross term is a covariance term that captures the effects on overall productivity of simultaneous changes in sectoral employment and productivity. For the purposes of this book, we combine the second and third terms into what we call the "structural change" term. Some authors, such as de Vries, Timmer, and de Vries (2015), estimate these terms separately, calling them the static and dynamic components of structural change. We find this confusing for two reasons. First, structural change by definition is a dynamic concept. And second, the third term alone is difficult to interpret when, for example, reductions in the employment share are accompanied by increases in productivity. This is because the term becomes negative, seemingly acting as a drag on productivity, when in fact it could be viewed as a positive development in such sectors as agriculture. 
By combining the second and third terms in equation (2), we arrive at the equation used by McMillan and Rodrik (2011) and by all of the country authors of this book:

$$
\Delta P_{t}=\sum_{i=1}^{n} \theta_{\mathrm{i}, \mathrm{t}-\mathrm{k}} \Delta P_{i, t}+\sum_{i=1}^{n} P_{i, t} \Delta \theta_{i, t}
$$

where Pt and pi,t refer to economywide and sectoral labor productivity levels, respectively, and $\theta \mathrm{i}, \mathrm{t}$ is the share of employment in sector $\mathrm{i}$ at time $\mathrm{t}$. The $\Delta$ operator denotes the change in productivity or employment shares between $\mathrm{t}-\mathrm{k}$ and $\mathrm{t}$. The implication of this decomposition is that economywide labor productivity growth can be achieved in one of two ways.

The first term — the "within-sector" component—captures how much of overall labor productivity growth can be attributed to changes within sec- tors. It is the weighted sum of productivity growth within individual sectors, where the weights are the employment share of each sector at the beginning of the time period. The second term - the "structural change" component - captures how much of overall labor productivity growth can be attributed to movements of workers across sectors. It is essentially the inner product of productivity levels (at the end of the time period) with the change in employment shares across sectors. When changes in employment shares are positively correlated with productivity levels, this term will be positive, and structural change will increase economywide productivity growth.

This decomposition clarifies how partial analyses of productivity performance within individual sectors (such as manufacturing or agriculture) can be misleading when there are large differences in labor productivities (pi,t) across economic activities. In particular, a high rate of productivity growth within an industry can have quite ambiguous implications for overall economic performance if the industry's share of employment shrinks rather than expands. For example, if the displaced labor ends up in activities with lower productivity, economywide growth will suffer and may even turn negative.

Armed with the results of the decomposition, the authors of each of the chapters then use a variety of strategies to gain a deeper understanding of the country-specific factors that played a role in facilitating (or impeding) structural change. For example, in Chapter 1 of this book, Mitra and Ahsan use state-level data on employment shares by industry, tariffs, education, and labor regulations to explore the correlates of structural change across states in India. 


\section{Country Studies: Data and Measurement Issues}

Here, too, in an effort to maintain consistency, all of the country studies use national accounts data and labor force statistics to compute measures of sectoral employment and value-added for nine broad sectors of the economy.

The authors also draw on several complementary datasets to conduct more detailed analyses of the underlying correlates of structural change and within- sector productivity growth. Country-specific data appendixes appear at the end of each of the country chapters. These appendixes document the sources of data, as well as any inconsistencies in the data and how these were handled. Nevertheless, several measurement issues common to all of the studies warrant clarification.

Informality. A big question with national output and employment data in developing countries is how well they account for the informal sector. The coverage of the informal sector in national accounts data varies from country to country (Timmer and de Vries 2009). While all countries make an effort to track the informal sector, obviously the quality of the data can vary greatly. In contrast, employment shares are more likely to include the informal sector, because they are typically obtained from nationally representative household surveys (labor force surveys or population censuses). A failure to account for activity in the informal sector will lead to an underestimate of value-added in activities that are heavily dominated by informality, such as agriculture.

Multiple jobs. In labor force surveys, workers are typically classified by their primary sector of employment. A potential concern with this classification is for individuals classified as "agricultural" but who work a substantial fraction of their hours in nonagricultural activities (Haggblade, Hazell, and Reardon 2007), as this would lead to an underestimate of labor productivity in agriculture. Gollin, Lagakos, and Waugh (2014) use Living Standards Measurement Study data for several developing countries to estimate labor productivity using hours worked; Adeyinka, Salau, and Vollrath do the same in Chapter 6 of this book on Nigeria. They find that the overwhelming majority of individuals classified as working in agriculture do in fact allocate almost all of their time to agriculture. Gollin, Lagakos, and Waugh (2014) also 
find that a significant portion of individuals in rural households is classified as working in nonagricultural activities.

Accounting for human capital. If human capital differs significantly across sectors, using the number of workers unadjusted for differences in human capital can be misleading. For example, if most of the labor in agriculture is unskilled and most of the labor in services is skilled, simple measures of productivity will understate labor productivity in agriculture and overstate labor productivity in services. One way to account for this is to adjust employment numbers for educational attainment, which is what Gollin, Lagakos, and Waugh (2014) do for their sample of countries (in the poorest countries, human capital is on average 1.4 times higher in the nonagriculture sector than in the agriculture sector). However, even after making this adjustment, they still arrive at the conclusion that average labor productivity in agriculture is significantly lower than average labor productivity in other economic sectors.

Average versus marginal productivity. The country authors of this book compare gaps in sectoral productivities using measures of average labor productivity, as is done in McMillan and Rodrik (2011) and Gollin, Lagakos, and Waugh (2014). It is well known that efficiency in wellfunctioning markets is characterized by an equalization of productivities at the margin. Under a Cobb-Douglas production function specification, the marginal productivity of labor is the average productivity of labor multiplied by the labor share. Thus, if labor shares differ greatly across sectors, comparing average labor productivities can be misleading. However, the existing evidence suggests that labor shares do not vary widely across sectors, except in a few activities (like public utilities) that typically do not absorb lots of labor (Mundlak, Butzer, and Larson 2012; Gollin, Lagakos, and Waugh 2014).

Quality of African statistics. Recently, concerns about the quality of Africa's national accounts data have been raised by a number of researchers, including Devarajan (2013) and Jerven and Johnston (2015). Like them, we think that the quality of national accounts data is intimately linked to Africa's growth and prosperity. Over the past decade or so, as growth in gross domestic product (GDP) has picked up in Africa, there has been a renewed focus on the quality of data - even leading to a rebasing of national accounts data for some countries. This is important, because of the rapid growth in small business activity that had previously been unrecorded. As a result, economies that did rebase saw significant gains in GDP per capita. In 
view of these issues, the authors of this book's African chapters have tried to collect data from a wide range of sources and to account for inconsistencies. For example, in the case of Botswana, the authors consider two scenarios for structural change in recent years, depending on assumptions about the share of the labor force in agriculture.

Failure to distinguish location. Most agriculture takes place in rural areas, and most manufacturing and services take place in urban areas. Given the higher costs of living in urban areas (particularly high cash rents), urban wages must typically exceed rural wages simply because of higher living costs. Thus, comparing nominal urban service and industrial wages with nominal rural farm wage rates inevitably leads to higher urban prices and wages. A more appropriate and purely sectoral comparison would involve comparing farm with rural nonfarm earnings or urban agriculture with urban unskilled manufacturing and service sector wage rates. We would guess that rental costs alone would require a 20 percent higher wage in urban areas, simply to maintain a standard of living comparable with rural areas.

In summary, while all of the measurement issues discussed above are important, we think that there is adequate evidence to support the approach taken by the authors of the country studies in this book. Adjusting average productivities for measurement error may diminish the labor productivity gaps uncovered, but it is highly unlikely that it would overturn any of the results.

\section{Country Studies: Findings}

\section{Significant Structural Changes, Different Outcomes: Vietnam and Ghana}

On the surface, Ghana and Vietnam appear to have much in common: big pools of labor in agriculture that over time move primarily into services, rather than manufacturing. But a closer look reveals how different their paths have been and, thus, why Vietnam is further along in its economic convergence.

In the late 1990s, Vietnam still had 70 percent of its workforce in agriculture, producing a third of the country's GDP. This discrepancy between agriculture's claim on the economy's resources and its contribution to out- put reflected the large differential in labor productivity across activities. 
The typical worker in manufacturing produced four times more output than the typical worker in agriculture. The typical worker in services such as construction or wholesale and retail trade produced even a bigger multiple than this. But over the next two decades, workers moved from lower- to higher-productivity activities (Figure O.3). In Chapter 2 of this book, McCaig and Pavcnik tell us that agriculture's employment share declined to 54 percent, while services' share rose from 18 percent to 32 percent, and manufacturing's share rose from 8 percent to 14 percent. During the 2000s, jobs in manufacturing grew at an annual rate greater than 10 percent, with the rate exceeding 15 percent in garments and reaching 30 percent in office and computing machines. The growth was particularly rapid in the

\section{FIGURE 0.3 Vietnam's workersmoveto higher-productivity sectors}

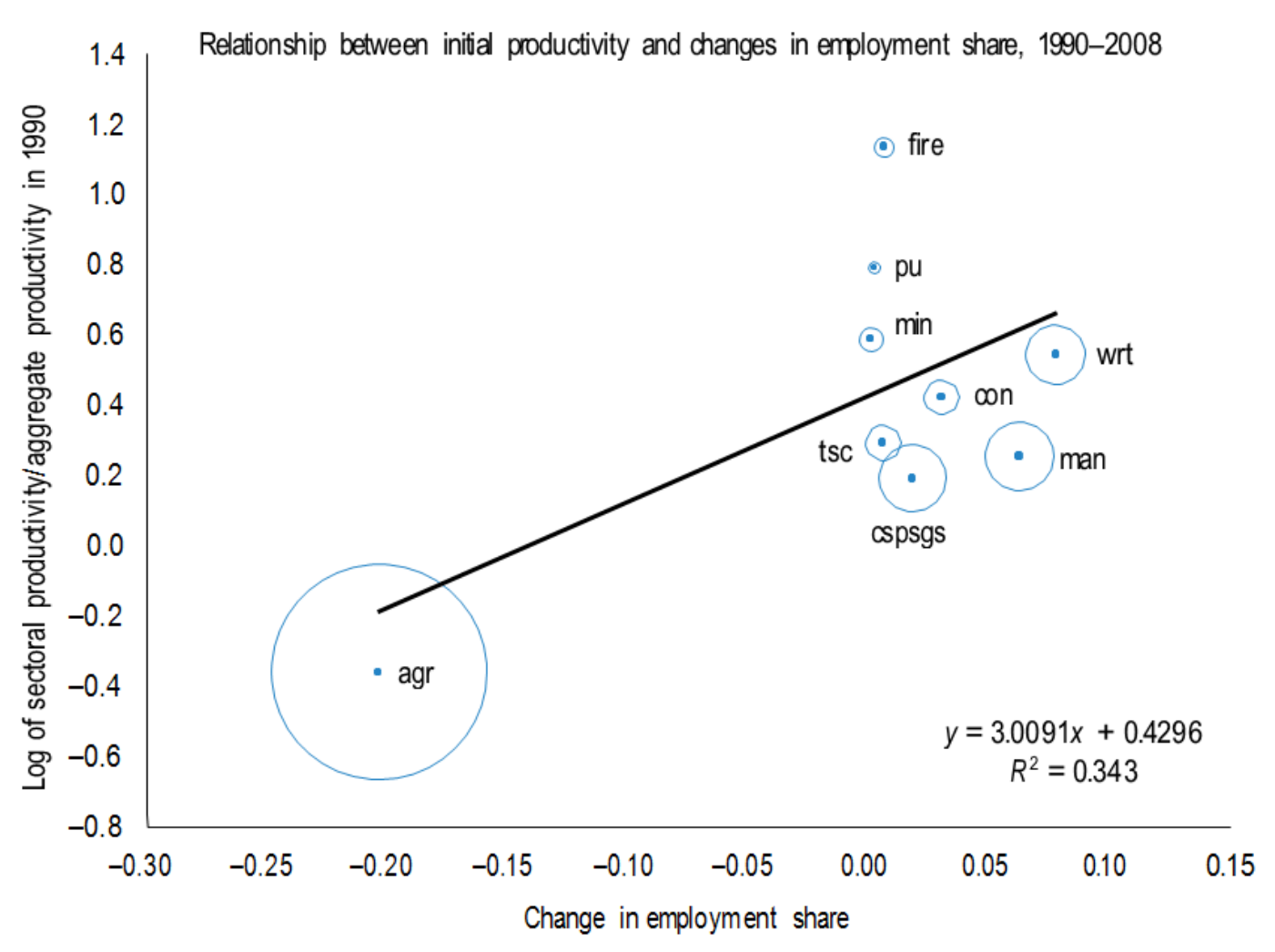

Southeast and Red River Delta, which entered the world economy on the back of export-oriented industrialization.

Vietnam's structural transformation came alongside two other import- ant shifts that were closely linked: (1) a transition from state-owned firms to private employment; and (2) a transition from family farms and businesses to formal, registered firms (particularly in 
manufacturing). These shifts contributed directly to productivity growth within sectors, but also enabled reallocation of factors of production across sectors. As a result, GDP per capita tripled in real terms over two decades, and poverty fell sharply, although McCaig and Pavcnik caution that large productivity gaps still exist both among and within sectors. Between 1990 and 2008, the growth in aggregate labor productivity was 5.1 percent per year, with structural change accounting for 38 percent of this increase and within-sector growth accounting for the rest.

In examining a case like Vietnam's - a clear-cut development success enabled greatly by structural transformation - ex post explanations are easy to come by. The country started with a large pool of "excess" labor in the country- side. The unexploited productivity gains from moving people from the farm to urban employment were huge. Relaxing the grip of state regulations and state- owned enterprises could unleash these hidden sources of productivity. In Vietnam this meant abolishing collective farms and replacing them with house- hold farms, titling land, liberalizing internal and external trade, and introducing competition and private businesses. Opening the country up to the world economy - through special economic zones and liberalization of investment rules — brought in foreign investment and technology, rendering modern sectors even more competitive. Encouraging exports enabled the expansion of manufacturing enterprises without running into market-size constraints.

Now consider Ghana, a country that has also done reasonably well in the 1990s and 2000s, certainly by African standards. In Chapter 4 of this book, Osei and Jedwab tell us that following a sharp decline in the 1970s, Ghana's real GDP per capita picked up from the mid-1980s on, with labor productivity registering annual growth of 3 percent between 1992 and 2010. Keep in mind this is only 60 percent of Vietnam's growth rate over the same period. While structural change appears to have contributed roughly half of the increase over this period-after contributing close to zero before then-a closer look indicates that the impact was highly uneven across subperiods (in fact, it was negative during 2000-2006).

While agricultural employment did decrease-dropping from 60 percent in 1980 to about 40 percent in 2010 - the labor that was released was absorbed mostly by low-productivity services, with limited impact on economywide productivity (Figure O.4). Moreover, the bulk of manufacturing took place in the informal sector, where productivity is more than 20 times lower than in the formal sector. Despite the apparent potential, industrialization has so far played a 
much more modest role in Ghana than in Vietnam. But to the extent it has played a role, Osei and Jedwab contend that "it has occurred without a green revolution, industrial revolution, or service revolution of the types seen, for example, in Asia." In our eyes, this assessment is rather troubling, in that a lack of these types of revolutions would inhibit the potential for progress on the structural change front. Keep in mind, as the authors point out, "there are still enormous hurdles on the socioeconomic front, with troubling levels of poverty, unemployment, and underemployment - especially for youths, and income inequality."

Why the difference between the two countries? It is tempting to ascribe Vietnam's superior performance to its government's liberalization policies

\section{FIGURE 0.4 BypassingindustryandintoservicesinGhana}

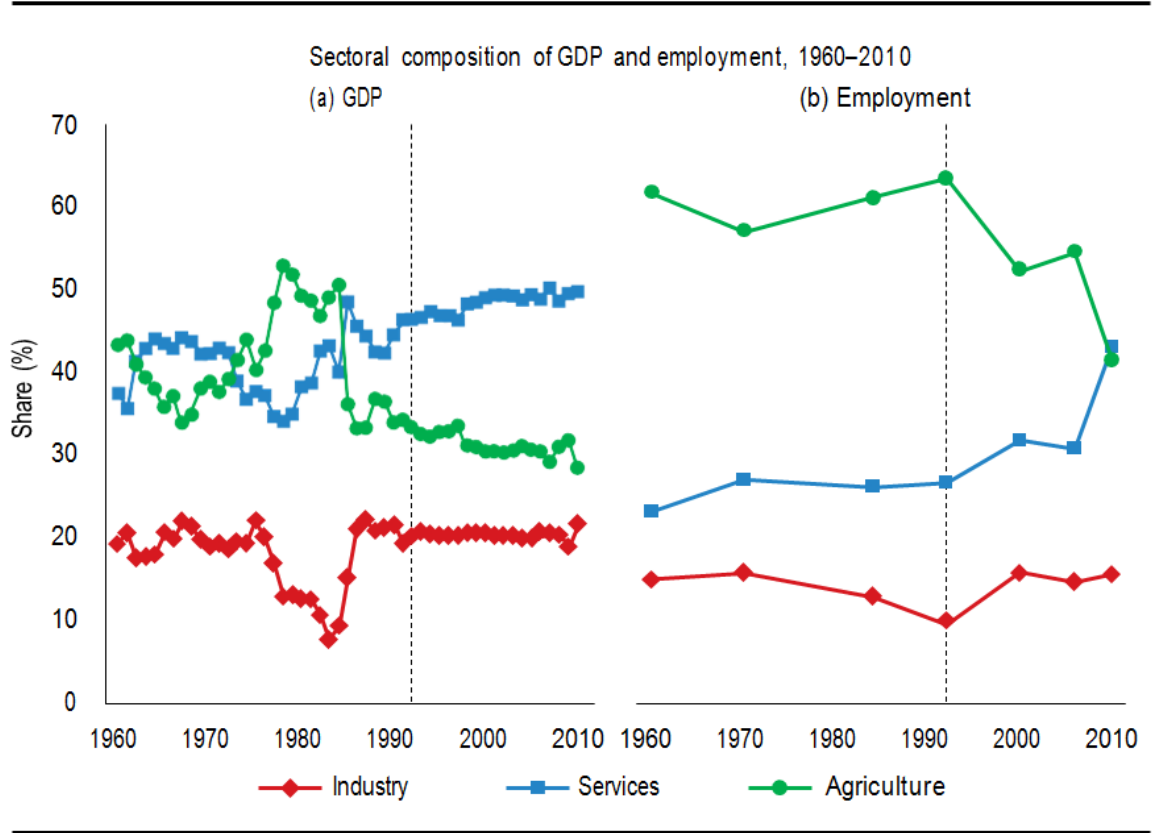

Source: Osei and Jedwab, chapter 4 in this book.

Note: Panel(a) plots thesectoral composition ofGDP, usingthree aggregate sectors: agriculture, industry, andservices Panel(b) plots the sectoral composition of employment, usingthesame three sectors. Employment data are available for the followingyears: 1960,1970,1984,1992,2000, 2006, and2010. The vertical dashed line is for 1992, the year whenthe nature of structural change was modified in Ghana.

and other efforts to remove obstacles facing private business. For example, in Chapter 2 McCaig and Pavcnik note that Vietnam was ranked 99th out of 185 countries in 2013 in the World Bank’s "Doing Business" indicators, "slightly behind China, ranked 91st, and ahead of such countries as Indonesia and Bangladesh." Yet Ghana ranks 27 countries ahead of Vietnam, in 64th place. According to the indicators, it was considerably easier to get credit in Ghana than in Vietnam, paying taxes was less of a hassle, insolvency was much more quickly resolved, and 
access to electricity was less problematic. In terms of how well investors are protected, there is a whop- ping 40-point difference between the two countries, in favor of Ghana.

Other cross-national indexes tell a similar story. The Cato Institute's Index of Economic Freedom, which attempts to quantify the extent to which economies are free of government encumbrance, ranks Vietnam in 96th place, compared with 71st place for Ghana (Gwartney, Lawson, and Hall 2012). (This is for 2010, which is the latest year for which data are available.) A reasonable objection to these comparisons would be that what matters is more the change than the level of an index. Economic progress may be more a function of how much policies have "improved" than where they stand at the end of the relevant period. But here too, it is hard to make the case that Vietnam looks better than Ghana. Both countries have undertaken significant reforms since the 1980s, opening up their economies to trade, reducing the role of the government, and deregulating. Ghana's summary rating on the Cato Index steadily rose (on a scale from 0 to 10) from 3.05 in 1980, to 5.53 in 1995, to 7.09 in 2010. Unfortunately, Cato does not provide a comparable series for Vietnam over the full period, so a direct comparison is not possible. But in light of the scale of improvement in Ghana's rating, it is difficult to imagine that Vietnam could have done much better. (To get a relative sense of these ratings, note that the United States had a rating of 7.70 in 2010.)

None of this is to deny the possibility that Vietnam's government does indeed provide a more hospitable environment than Ghana for private business, both by nurturing new economic activities and by removing obstacles that existing ones face. The point is that the way such an environment is constructed is subtler than what is captured by standard indexes and conventional types of policy advice. Although economic liberalization and removal of red tape may foster private investment, the comparison with Ghana suggests it would be a mistake to describe Vietnam's strategy in those terms - or those terms alone. Of course, a similar argument could be made for many other East Asian success stories as well.

Vietnam's spectacular growth is also likely to be partly driven by a strong commitment to improving the fundamentals. Vietnam outshines Ghana on all standard measures of education and infrastructure. Its investment rate is 35 percent, while Ghana's is only 25 percent. Industrial policy in Vietnam appears to be focused on increasing exports in all sectors. At the start of the reforms in the late 1980s, Vietnam was a net importer of rice, and agricultural exports were 
paltry. Today, it is the second-largest exporter of rice, and the country has become a major player in the international coffee market. In fact, Vietnam runs a sizable trade deficit in manufactured goods, which is covered by agricultural and oil exports. Thus, while it is true that productivity growth has been the highest in export-oriented manufacturing, it would be incorrect to attribute all or even most of Vietnam's success to its success in manufacturing. Rather, the deeper reason for Vietnam's success in manufacturing is likely to be the same reason for its success in other export- oriented sectors.

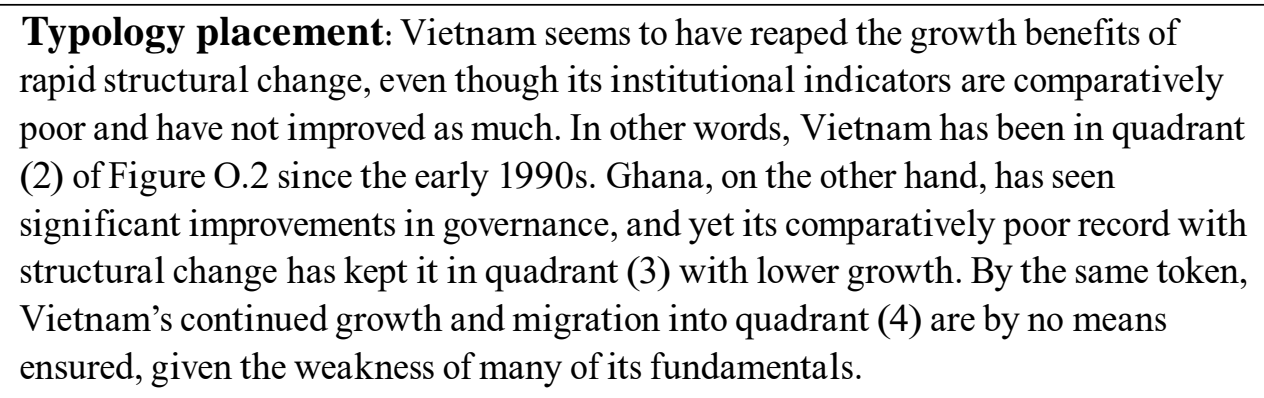

\section{Limited Structural Change, Enormous Potential: India, Nigeria, and Zambia}

India, Nigeria, and Zambia provide an interesting contrast. On paper, these countries have the makings of industrial success stories, with their large endowments of relatively unskilled labor still in rural areas and their enormous domestic markets. Yet all three have underperformed remarkably on this dimension, and it is clear that all of them would benefit greatly from greater attention to the fundamentals.

Over the past 50 years, as we learn from Ahsan and Mitra in Chapter 1, agriculture's share of employment in India has fallen by roughly 20 percentage points - from about 70 percent in 1960, to 60 percent in 2004, to 50 percent in 2011-with the sector now contributing about 15 percent of GDP, sharply down from around 40 percent in 1960. However, manufacturing's labor share has barely changed over this time period, from 10 percent in 1960 to 12 percent today, with the GDP share unchanged at 13 percent. To put these numbers in perspective, Vietnam was able to achieve more than double this rate of industrialization in less than half the time. For India, the biggest labor movement has been into services (up from 18 percent in 1960 to 28 percent in 2011), with the GDP share rising to nearly 60 percent (up sharply from just below 40 percent in 1960). 
Structural change did make a positive contribution to growth in India after the 1990s, especially during the first decade after the 1991 reforms. But the biggest part of that came from the expansion of finance, insurance, and other business services, with manufacturing actually shrinking and making a negative contribution during 2000-2004 (Figure O.5a). Information technology and business process outsourcing services, on which India's recent growth has relied, are no doubt high-productivity activities with convergence dynamics that may be even stronger than in manufacturing. But they are also highly skill-intensive sectors, unable to absorb the vast majority of the Indian workforce that remains poorly educated. As a consequence, India's underlying growth trend is suppressed by the necessarily slow accumulation of fundamental capabilities - education, infrastructure, and governance — in the economy as a whole.

Moreover, Ahsan and Mitra report that while manufacturing was the leading contributor to within-sector productivity growth in 2000-2004 (Figure O.5b), it fell in terms of its employment share during these years (even though its labor productivity was higher than the economywide aver- age). Thus, they stress the need for overhauling restrictive labor regulations, "especially because the future potential of agriculture and services in generating overall growth is limited (beyond a point) at India's stage in the development process."

At the state level, the authors find that two of the fastest-growing states between 1998 and 2004 followed strikingly different growth paths. For Gujarat, all of the growth came from withinsector change; in fact, structural change was slightly negative, unlike the rest of the states, which enjoyed some positive structural change (Figure O.6). In contrast, in Maharashtra, the withinsector and structural change components were about the same. The only state that experienced negative within-sector change was Assam.

The story in Nigeria is not that different. In Chapter 5, Adeyinka, Salau, and Vollrath show that between 1996 and 2009 (not including petroleum), the share of employment in agriculture fell only slightly, from 66 percent 
FIGURE 0.5a Finance, insurance, real estate, and business services is contributing most to India's structural change ...

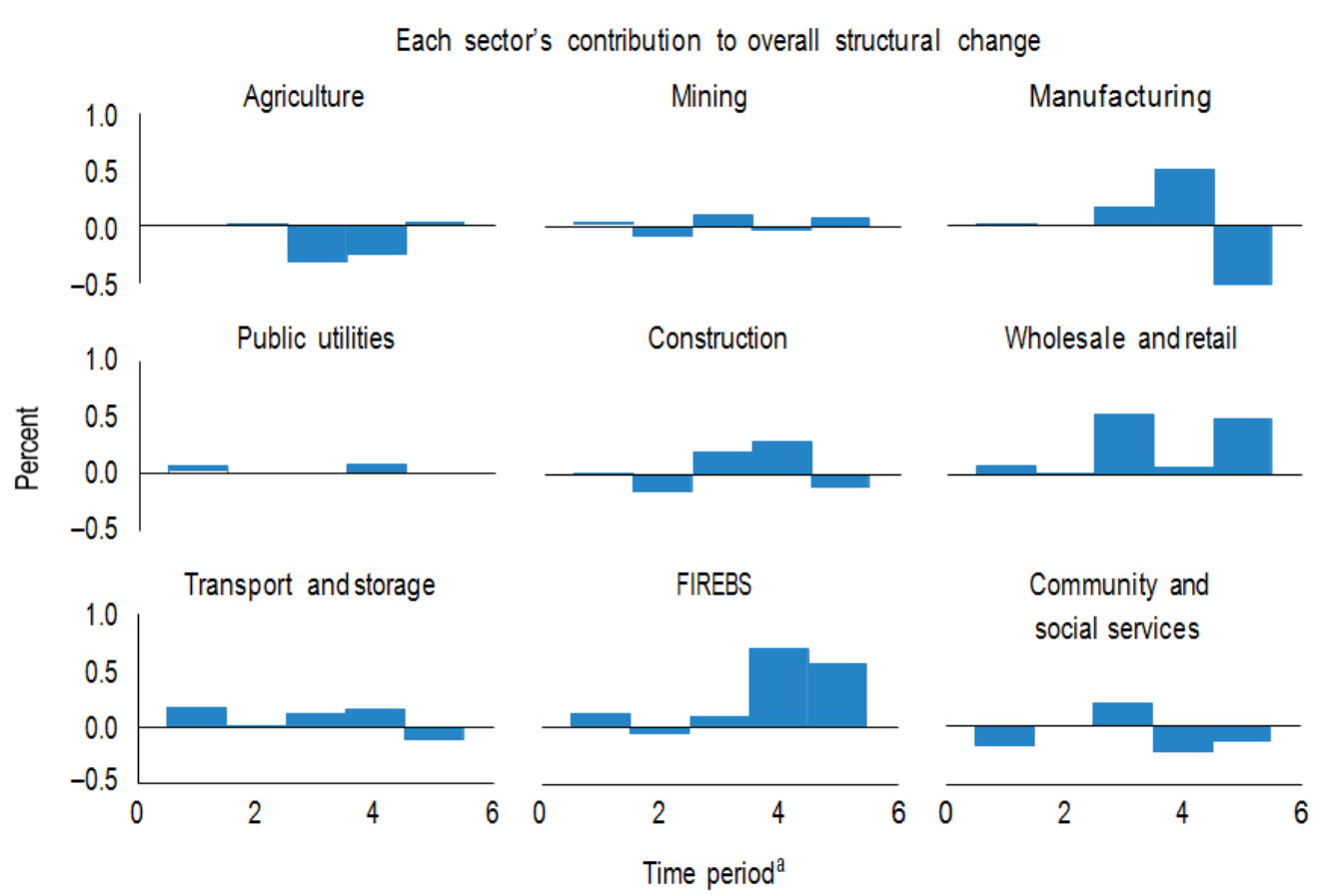

FIGURE 0.5b ... and since 2000 , manufacturing is helping its "within-sector"change

Each sector's contribution to overall with-sector structural change
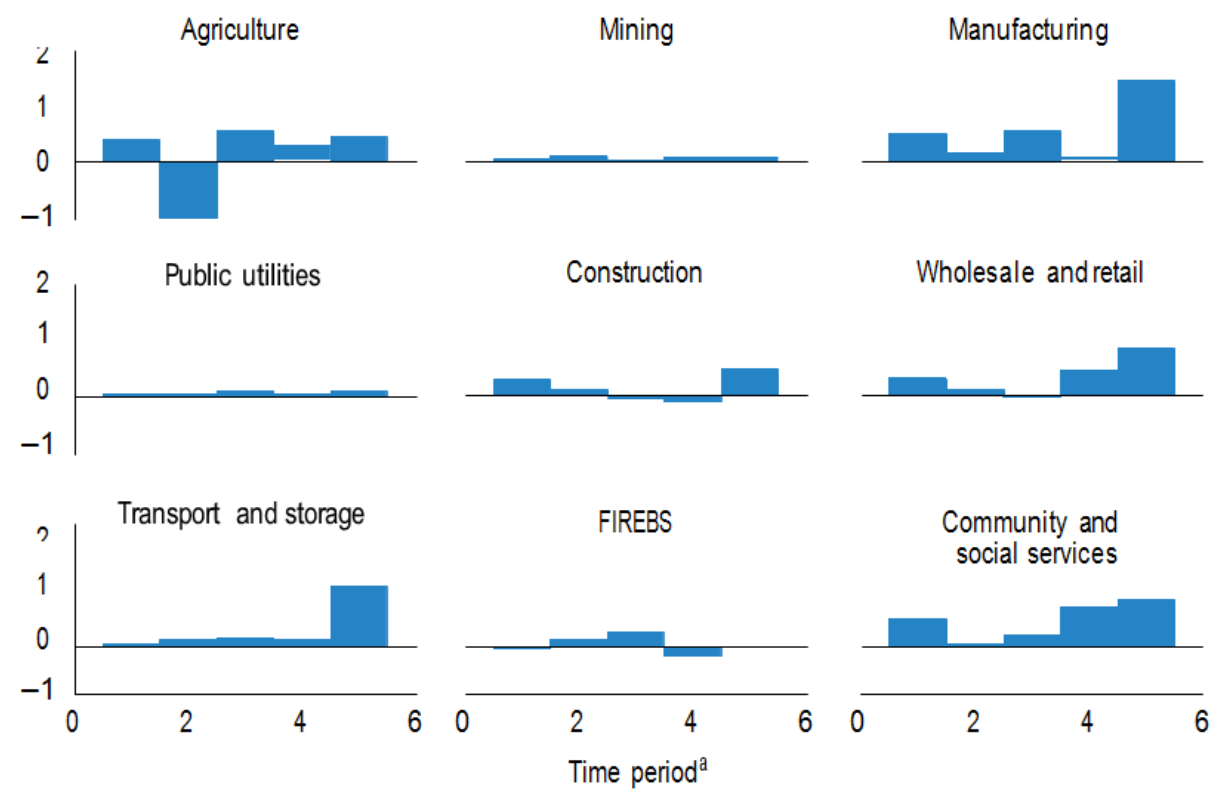

Source: AhsanandMitra, chapter 1 inthis book.

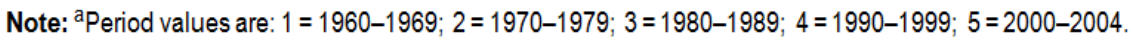

FIREBS = finance, insurance, real estate, and business services. 
FIGURE0.6 Gujarat and Maharashtra follow significantly different growth paths

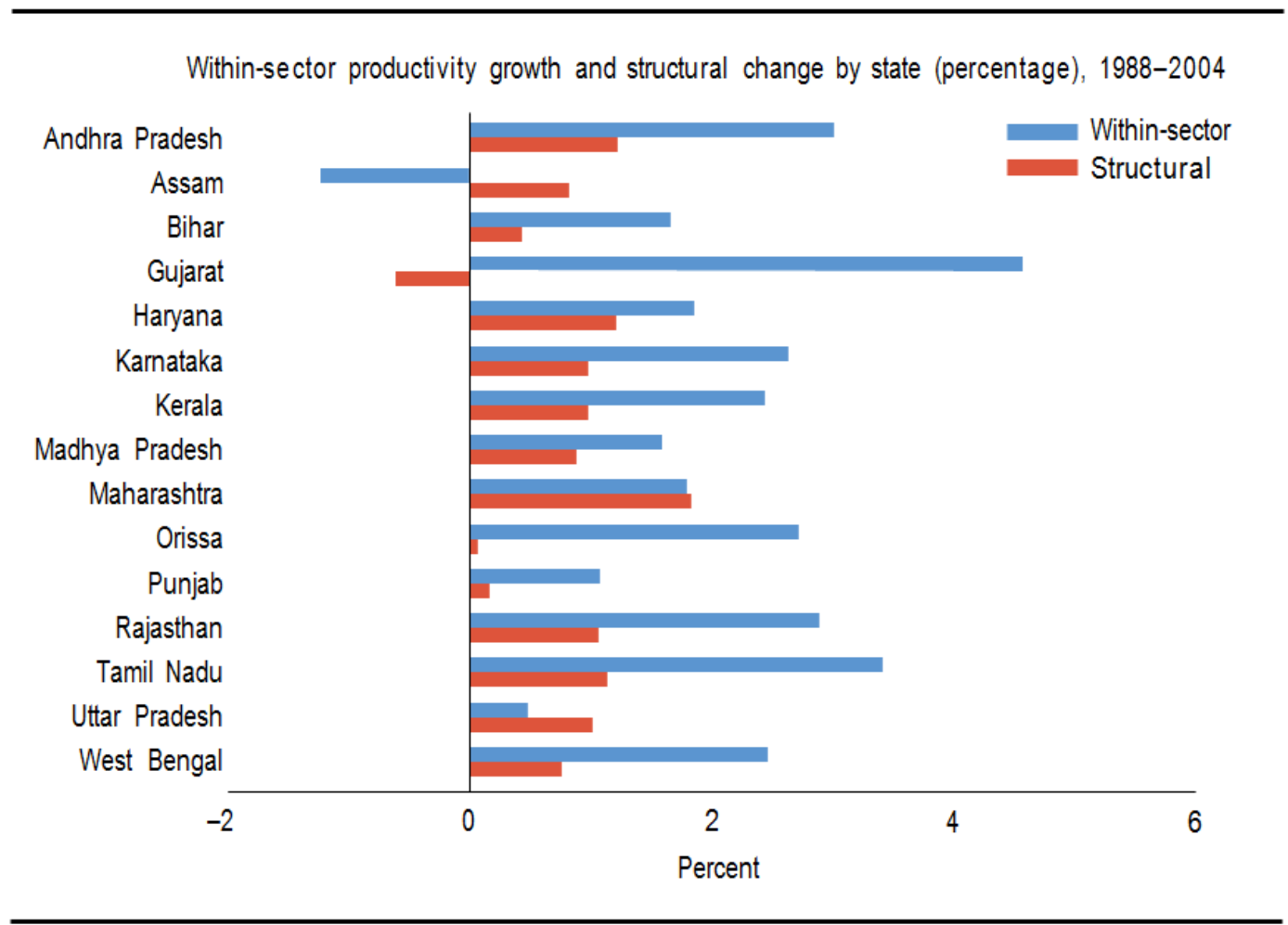

Source: AhsanandMitra, chapter 1 inthisbook.

to a little more than 60 percent (still the dominant sector at 40 percent of GDP), while the share of employment in manufacturing increased by a meager 2.2 percentage points to 4.1 percent (accounting for only about 10 percent of GDP). Over this same period, average annual productivity growth was 4.5 percent for the nonpetroleum economy, but the lion's share of this growth (3.5 percent) was accounted for by within-sector productivity improvements. If petroleum (oil and gas) — which employs less than 1 percent of the labor force but accounts for 20-30 percent of GDP - is included, productivity rose less but structural change played a bigger role (Table O.1). The authors suggest that productivity gains could have been as much as 54 percent greater had structural change been greater. They see the key levers for this to occur as (1) stimulating agricultural production, (2) liberalizing trade policies, (3) upgrading infrastructure, and (4) improving human capital.

A worrying feature of the Nigerian economy is that productivity growth in manufacturing between 1996 and 2009 was actually negative relative to agriculture. The reasons for this are 
unclear. One explanation may be that people entering the manufacturing workforce are in the informal sector, as in Ghana and several other African countries. Another explanation

\begin{tabular}{|c|c|c|c|c|}
\hline \multicolumn{5}{|c|}{ Components of labor productivity change, 1996-2009 } \\
\hline \multirow[b]{2}{*}{ Growth decomposition } & \multicolumn{4}{|c|}{ Time periods } \\
\hline & 1996-1999 & 1999-2005 & 2005-2009 & 1996-2009 \\
\hline \multicolumn{5}{|l|}{ PanelA:Excluding oil and gas } \\
\hline$\%$ annual productivity growth & 0.8 & 4.8 & 7.0 & 4.5 \\
\hline \multicolumn{5}{|l|}{ ofwhich: } \\
\hline$\%$ within-sector productivity & -2.0 & 9.4 & 2.6 & 3.5 \\
\hline$\%$ structural change & 2.8 & -4.6 & 4.4 & 1.0 \\
\hline \multicolumn{5}{|l|}{ Panel B: Including oil and gas } \\
\hline$\%$ annual productivity growth & -0.8 & 4.4 & 4.1 & 2.9 \\
\hline \multicolumn{5}{|l|}{ ofwhich: } \\
\hline$\%$ within-sector productivity & -7.1 & 6.2 & -1.6 & 0.7 \\
\hline$\%$ structural change & 6.3 & -1.8 & 5.7 & 2.2 \\
\hline
\end{tabular}

Source: Adeyinka, Salau, and Vollrath, chapter 5 in this book.

may have to do with Nigeria's low levels of fundamentals (such as infrastructure and human capital). However, to explain negative productivity growth, these conditions would have had to deteriorate. In addition, large productivity gains were made in wholesale and retail trade, transportation and communications, agriculture, and general services. This is puzzling, because it is not obvious why fundamentals would matter more for manufacturing than for other sectors. That said, Nigeria's record on this front is inexcusable.

In 2010, only half of Nigeria's population was literate, life expectancy was 51 years, only 15 percent of the roads were paved, electric power consumption was only 135 kilowatt-hours per capita, and investment stood at only 17 percent of GDP.

As for Zambia - a country that reclaimed its "middle-income" status in the 2000s thanks to rapid growth - the story is one of extremely uneven structural change. In Chapter 6, Resnick and Thurlow find that structural change was an overall drag on economic growth in Zambia between 1991 and 2010, as labor productivity grew by only 0.31 percent. But if that period is divided into two subperiods, a more nuanced picture emerges. Between 1991 and 2001, there was a mass exodus out of urban areas as copper mines and other parastatals shut down during a phase of privatization, with the share of employment in agriculture (the sector with the lowest productivity) actually increasing (Table O.2). 
Table 0.2 Agriculture is driving Zambia'sjobgrowth butnot GDP

\begin{tabular}{lrrrrrr}
\hline \multicolumn{5}{c}{ Drivers of GDPand formal employment growth, 1991-2010 } \\
\cline { 2 - 7 } & \multicolumn{5}{c}{ GDP (millions of 2002 US\$) } & \multicolumn{2}{c}{ Employment (1,000s people) } \\
\cline { 2 - 7 } Sectors & Initial & \multicolumn{7}{c}{ Change over period (\%) } & Initial & Change over period (\%) & \\
\cline { 2 - 7 } Value (uS\$ millions or & \multicolumn{7}{c}{1991} & $1991-2002$ & $2002-2010$ & 1991 & $1991-2002$ & $2002-2010$ \\
1,000s people) & 8,410 & 1,023 & 6,108 & 2,519 & 1,001 & 865 \\
contribution (\%) & 100.0 & 100.0 & 100.0 & 100.0 & 100.0 & 100.0 \\
agriculture & 15.2 & 30.5 & 8.1 & 65.4 & 87.6 & 51.4 \\
mining & 20.1 & -84.4 & 13.6 & 1.9 & 0.2 & 1.0 \\
manufacturing & 10.7 & 21.3 & 6.8 & 4.3 & 1.4 & 1.3 \\
utilities & 3.3 & 2.6 & 1.6 & 0.9 & -1.2 & 0.7 \\
construction & 8.4 & -8.0 & 21.9 & 1.9 & -0.3 & 4.2 \\
Trade & 17.3 & 49.3 & 9.8 & 10.3 & 4.8 & 19.6 \\
Hotels, catering & 1.2 & 14.0 & 2.5 & 0.5 & 1.9 & 1.3 \\
Transport, communications & 6.1 & 12.1 & 16.5 & 2.9 & -1.5 & 3.7 \\
Finance, business services & 9.8 & 48.8 & 9.0 & 1.8 & 0.6 & 6.1 \\
Government & 7.1 & 11.4 & 8.9 & 5.6 & 6.7 & 6.7 \\
Other services & 0.7 & 2.3 & 1.4 & 4.5 & -0.2 & 4.1 \\
\hline
\end{tabular}

Source: Resnick and Thurlow, chapter 6 in this book.

But starting in 2002, the share of employment in agriculture began to fall, with services absorbing most of the workers who left the farm. Although the services sector is dominated by small-scale informal activity, its activities are still more productive than subsistence agriculture. Mining staged an impressive recovery, but only accounted for 1 percent of the new jobs created. And manufacturing not only failed to rally, but actually continued its decline. In the end, structural change and within-sector growth each accounted for around half of the 3.56 percent increase in labor productivity between 2002 and 2010. However, Resnick and Thurlow emphasize that the renewed growth and positive structural change have not translated into social transformation - a reality that has been reflected "in the country's shifting political landscape," and one that they contend can be seen playing out elsewhere in Africa, even in countries without large-scale mineral resources.

With more than half of the population engaged in low-productivity agriculture, structural change could play a significant role in Zambia's growth going forward. But it may well be that to realize this potential, Zambia must first invest more in its fundamentals. Gross fixed capital formation as a share of GDP was only 22 percent in 2010, and physical and human infrastructures are still comparatively low. 
Typology placement: India, Nigeria, and Zambia have not had the full benefit of quadrant (2), and India in particular has hovered not too far from quadrant (1). For all of them, investing in the fundamentals is now critical.

\section{No Structural Change in Recent Years: Botswana and Brazil}

Unlike the rest of the countries featured in this book, Botswana and Brazil have been middleincome countries for some time. Structural change played a significant role in catapulting these countries into middle-income status, but its role has been more muted in the past two decades. Their stories, though, are quite different.

In Brazil, structural change was rapid from the 1950s through the 1970s (especially in the 1950s and early 1960s), accounting for 40 percent of total labor productivity growth during this period (Figure O.7). As agricultural employment shrank, manufacturing jobs expanded slightly, and modern service activities - the most productive sector — absorbed the bulk of the labor. By the late 1970s, industries as a whole accounted for close to 40 percent of total labor productivity growth. This period of high-growth, rapid structural change was one

FIGURE 0.7 Within-sector changes in Brazil swamping structural changes

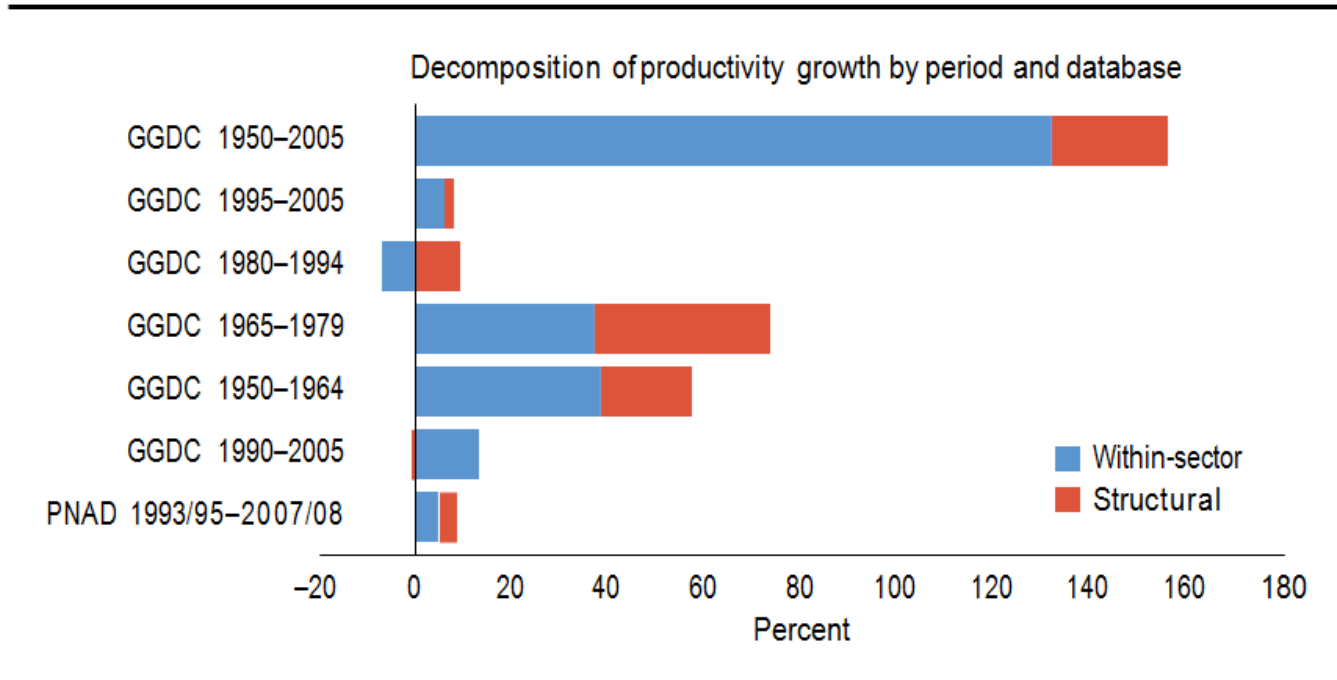

Source: Firpo and Pieri, chapter 7 in this book.

Note:The bars correspond to growth rates for the whole period indicated. For example, for the period 1950-2005, using Groningen (GGDc)data, laborproductivityresultingfromthewithin-sectorandstructuralchangeeffectsgrewby 132 percentand 24 percent, respectively. GGDc = Groningen Growth Development centre; $\mathrm{PnaD}=$ Pesquisa nacional por amostra de Domicilios.

in which policies of import substitution predominated. (It goes without saying that such policies are anomalous from the perspective of the World Bank's Doing Business database and Cato 
Institute's Economic Freedom indicators [World Bank, various years; Gwartney, Lawson, and Hall 2012]).

But in Chapter 7, Firpo and Pieri argue that by the late 1970s, the country had run out of room for continuous and long-term structural change, at least along broad intersectoral lines, and had to rely on within-sector enhancements - like investing in human capital and new technologies (in agriculture especially) and improving institutions. In fact, they assert that efforts aimed at reversing this natural trend (by enlarging manufacturing and contracting agriculture) failed "and the early years of the 1980 s of slow growth can serve as evidence of those efforts."

So what path remains open for Brazil today? The authors argue that the Brazilian experience suggests a return to the old policies is likely to fail. They believe horizontal, across-the-board policies are more likely to spur productivity within sectors than selective policies that give priority to some sectors over others. Given where Brazil stands in term of its stage of development, it is reasonable to expect that future growth will have to rely predominantly on investment in fundamentals (institutions and human capital), and that broad patterns of structural change will play a comparatively small role. In particular, it will be difficult for Brazil to reindustrialize. But there are still strategic opportunities that could be exploited by a nimble government. If used well, the country's deep-water oil reserves should boost not only oil exports but also a range of associated services and industries at home.

As for Botswana, its story is similar to Brazil's, in that the share of employment in agriculture fell dramatically between 1970 and 1990. But unlike Brazil, the decline in agriculture's share of employment was almost entirely matched by an increase in the share of the labor force in services. Moreover, numerous government efforts to industrialize never succeeded (perhaps not surprising for a small landlocked country). The authors of Chapter 3-McCaig, McMillan, Verduzco-Gallo, and Jefferis - point to two distinct periods in Botswana's economic evolution. Between 1970 and 1989, they find that labor productivity grew at an average of 8 percent per year, with structural change playing a major role in this spectacular growth, especially in the 1970s (Figure O.8). But in the decades that followed, labor productivity slowed to 1.9 percent per year, driven entirely by within-sector productivity growth - with structural change an actual drag on growth in the 2000s. 
Historically, diamonds played a significant role in fueling Botswana's economic growth, although this has changed in recent years. Between 1968 and 2010, economic activity shifted out of agriculture, first to mining and later to

\section{FIGURE 0.8 Fromabig role for structural change in Botswanato a drag ongrowth}

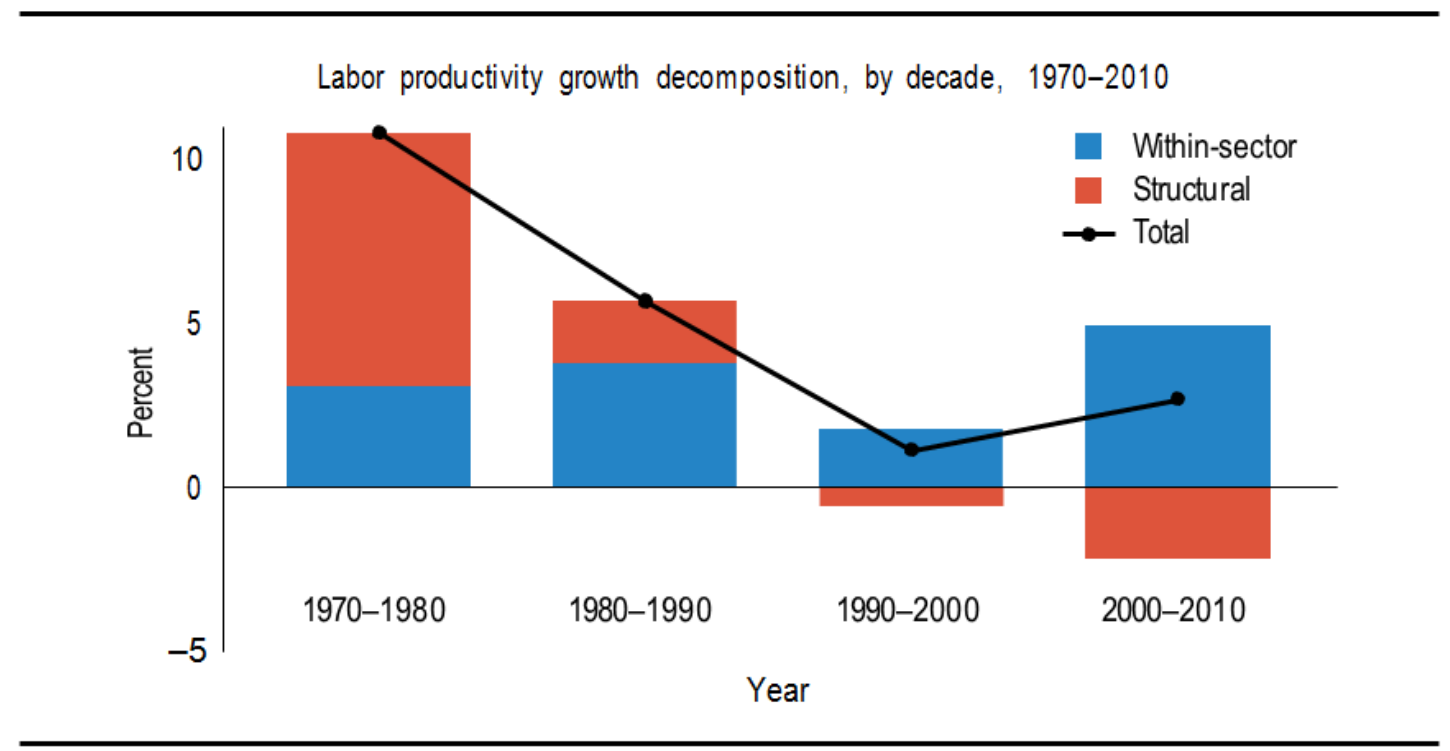

Source: McCaig et al., chapter 3 inthis book.

Note: Graph shows decomposition of average annual labor productivity growth (value-added in 2005 output per worker) during each decade.

services. In 2010, diamonds made up only 17.7 percent of value-added and a mere 1.5 percent of total employment. In contrast, the share of services in value-added reached 64.4 percent, while the share of services in employment reached 50.6 percent. Although the share of employment in agriculture remains high at 38.6 percent, its share in value-added has dropped from 27.4 percent to 2.7 percent — an indication of agriculture's abysmal performance in Botswana.

An interesting feature of both Brazil's and Botswana's economies is that trade liberalization in the early 1990s did not have a major impact on the structure of either economy, although it did give a sharp boost to within-sector productivity. This limited impact on the structural front is especially surprising in Brazil, where manufacturing has been central to the economy. Also unlike Brazil, Botswana does not have the same potential in agriculture, as most of the land inhabited by farmers is semi-arid and prone to drought. For both of these countries, growth is more likely to come from improvements in fundamentals that facilitate within-sector productivity growth. 
Typology placement: The expectation was that Brazil would move from quadrant (1) to quadrant (4); but the country instead ended up in quadrant (3), with much-improved fundamentals, but also sharply reduced growth. Botswana is similarly stuck in quadrant (3), with slow growth and relatively strong fundamentals, although unlike Brazil, it has never industrialized.

\section{The Verdict on Structural Change versus Within-Sector Productivity Growth}

So what do these findings on individual countries add up to in terms of broad trends in structural change? We believe this book provides a worthwhile insight in that, although we are only examining seven country studies, these countries together represent about 22 percent of developing country GDP and 30 percent of developing country population. Moreover, within their respective regions, some of these countries matter greatly-like Nigeria (19 percent of Sub-Saharan Africa's GDP and 19 percent of the region's population), India (82 percent of South Asia's GDP and 75 percent of the region's population), and Brazil (35 percent of Latin America and the Caribbean's GDP and 34 percent of the region's population).

Overall, our country sample shows that the past two decades have seen extraordinary growth and rapid catch-up convergence in developing countries - underpinned by increases in labor productivity — although the patterns of within-sector versus structural change increases vary widely (Table O.3).

Nonetheless, a few themes emerge at the regional level.

Africa. Labor productivity rose in all four countries during the 2000s, with the second half of the period characterized by a resurgence of structural change as a driver of productivity growth in Nigeria and Zambia, and to a lesser extent in Ghana. Botswana, the only upper-middle-income country in the African sample, resembles a Latin America country in the sense that most of the productivity stems from within-sector growth rather than from structural change. These results are consistent with McMillan and Harttgen (2014), who show that structural change was growth enhancing in Africa post-2000.

Asia. In this region, India and Vietnam represent stark contrasts in terms of what has driven labor productivity increases. In Vietnam, structural change has been a strong driver throughout 
the period. However, in India, most of the productivity growth has come from within-sector productivity. In fact, the contribution of structural change decreased in the 2000s from the 1990s, down from 1.3 percent to 0.3 percent - a definite worrying sign for a country that still has a large portion of the population working in the agriculture sector.

Latin America. Brazil exemplifies an upper-middle-income country that has already undergone a deep structural transformation, moving a large share of workers from agriculture to manufacturing by the end of the 20th century. Over the past two decades, however, the country has strongly relied on within-sector productivity change-in fact, gains in structural change are minimal. 
Table 0.3 Africanand othercountriesseeing structural changeinthe21stcentury

\begin{tabular}{|c|c|c|c|}
\hline \multirow[b]{2}{*}{ Country } & \multicolumn{3}{|c|}{ Labor productivity growth (percent) } \\
\hline & Total & Within & Structural \\
\hline \multicolumn{4}{|l|}{ Botswana } \\
\hline 1990-2000 & 1.1 & 1.7 & -0.6 \\
\hline 2000-2010 & 2.7 & 4.9 & -2.2 \\
\hline \multicolumn{4}{|l|}{ Ghana } \\
\hline $1992-2000$ & 1.0 & -0.9 & 2.0 \\
\hline 2000-2006 & 4.5 & 6.0 & -1.5 \\
\hline $2006-2010$ & 2.7 & 0.0 & 2.6 \\
\hline \multicolumn{4}{|l|}{ Nigeria } \\
\hline 1996-1999 & -0.8 & -7.1 & 6.3 \\
\hline 1999-2005 & 4.4 & 6.2 & -1.8 \\
\hline 2005-2009 & 4.1 & -1.6 & 5.7 \\
\hline \multicolumn{4}{|l|}{ Nigeria, excluding oil andgas } \\
\hline 1996-1999 & 0.8 & -2.0 & 2.8 \\
\hline 1999-2005 & 4.8 & 9.4 & -4.6 \\
\hline 2005-2009 & 7.0 & 2.6 & 4.4 \\
\hline \multicolumn{4}{|l|}{ Zambia } \\
\hline $1991-2002$ & -2.0 & 0.0 & -2.0 \\
\hline 2002-2010 & 3.6 & 1.8 & 1.8 \\
\hline \multicolumn{4}{|l|}{ India } \\
\hline 1990-1999 & 2.9 & 1.7 & 1.3 \\
\hline 2000-2004 & 6.5 & 6.2 & 0.3 \\
\hline \multicolumn{4}{|l|}{ Vietnam } \\
\hline 1990-2008 & 5.1 & 1.9 & 3.1 \\
\hline $1990-2000$ & 5.2 & 1.0 & 4.2 \\
\hline $2000-2008$ & 4.9 & 2.7 & 2.2 \\
\hline \multicolumn{4}{|l|}{ Brazil } \\
\hline 1995-2005 & 0.8 & 0.6 & 0.2 \\
\hline 1990-2005 & 0.8 & 0.8 & -0.0 \\
\hline 1993/1995-2007/2008 & 0.5 & 0.3 & 0.2 \\
\hline
\end{tabular}

Source: Botswana-Value-added and employment data are from the Groningen Growth and Development Centre Africa Sector Base; Ghana—Economic Survey of Ghana 1961-1982; population and housing censuses 1960, 1970, 1984, 2000, and 2010; Ghana Living Standard Survey 1991-1992 and 2005-2006; Singal and Nartey (1971); Androe (1981); Ewusi (1986); GSS (2010); and World Bank (2010); Nigeria - Output data are from the Nigerian Bureau of Statistics. Employment data are from the Nigeria General Household Survey (GHS) [1996-2011];Zambia_Data are from the Central Statistics Office [1993, 2004, 2011, and 2012.]; India-Value-added and employment data are from the Groningen Growth and Development; Vietnam - Employment, gross domestic product (in constant 1994 prices), and labor productivity (also in constant 1994 prices) data are from the General Statistics Office of Vietnam; Brazil-For the period 1950-2005, value-addedand employmentdata are from the Groningen Growth and DevelopmentCentre. For the period 1993/1995-2007/2008, data are from Pesquisa Nacional por Amostra de Domicílios.

Note:Botswana-Data are disaggregated at 10 sectors, as in Mcmillanand Rodrik (2011); Ghana—Data are disaggregated at 9 and 14 sectors; Nigeria - Data are disaggregated at 9 sectors; Zambia -Data are disaggregated at 9,10 , or 3 sectors; India-Data are disaggregated at 10 or 9 sectors. Vietnam-Data are disaggregated into 19 economic sectors; Brazil-Dataaredisaggregatedat 10 sectors, as in Mcmillanand Rodrik (2011). 


\section{The "Double Whammy" of Manufacturing}

Like India, African countries seem to be bypassing the industrialization stage that was so important to Brazil's and Vietnam's rapid growth. In fact, the share of employment in African manufacturing is still only roughly half the share in Asian manufacturing (McMillan 2013). Instead, to the extent that structural change is taking place, it is primarily fueled by an expansion in services. To understand the ramifications of this pattern, it is important to understand the role that manufacturing has played in the past.

A manufacturing-based growth strategy has two distinct advantages. First, a great deal of manufacturing is labor intensive, so it can absorb large amounts of relatively unskilled workers from other sectors at a substantial productivity premium. It is comparatively easy to turn a rice farmer into a garment factory worker, without significant investment in human capital and with manageable investment in physical capital. And the industrialization process can go on for quite some time - several decades — during which income and productivity levels converge with those of rich countries.

Second, manufacturing — specifically, formal manufacturing — exhibits a remarkable property known as "unconditional convergence." That is, it takes place regardless of the quality of domestic policies or institutions and other aspects of economic context, such as geography and infrastructure (Rodrik 2013b). For developing countries, where lagging manufacturing sectors are the norm, labor productivity tends to catch up with the productivity of developed countries, where technologies are the most advanced as if on an automatic escalator, at a rate of 2-3 percent per year. The greater the distance from the productivity frontier, the faster the rate of productivity growth. Of course, the better the environment, the more rapid the convergencethat is, conditional convergence is even more rapid (Rodrik 2013b).

Unconditional convergence can be visualized in Figure O.9, which maps the relationship between initial labor productivity in manufacturing industries for 21 countries in Sub-Saharan Africa (including Ghana) and their growth rates in the subsequent decade. The negative slope of the scatter plot captures the essence of unconditional convergence. The trend is as unmistakable in Africa as it is elsewhere. Perhaps this outcome is not surprising, given that these industries produce tradable goods and can be rapidly integrated into global production networks, 
facilitating technology transfer and absorption. Even when they produce just for the home market, these industries operate under a competitive threat from efficient suppliers from abroad, requiring them to upgrade their operations and remain efficient.

\section{FIGURE 0.9 UnconditionalconvergenceisaliveandwellinAfrica}

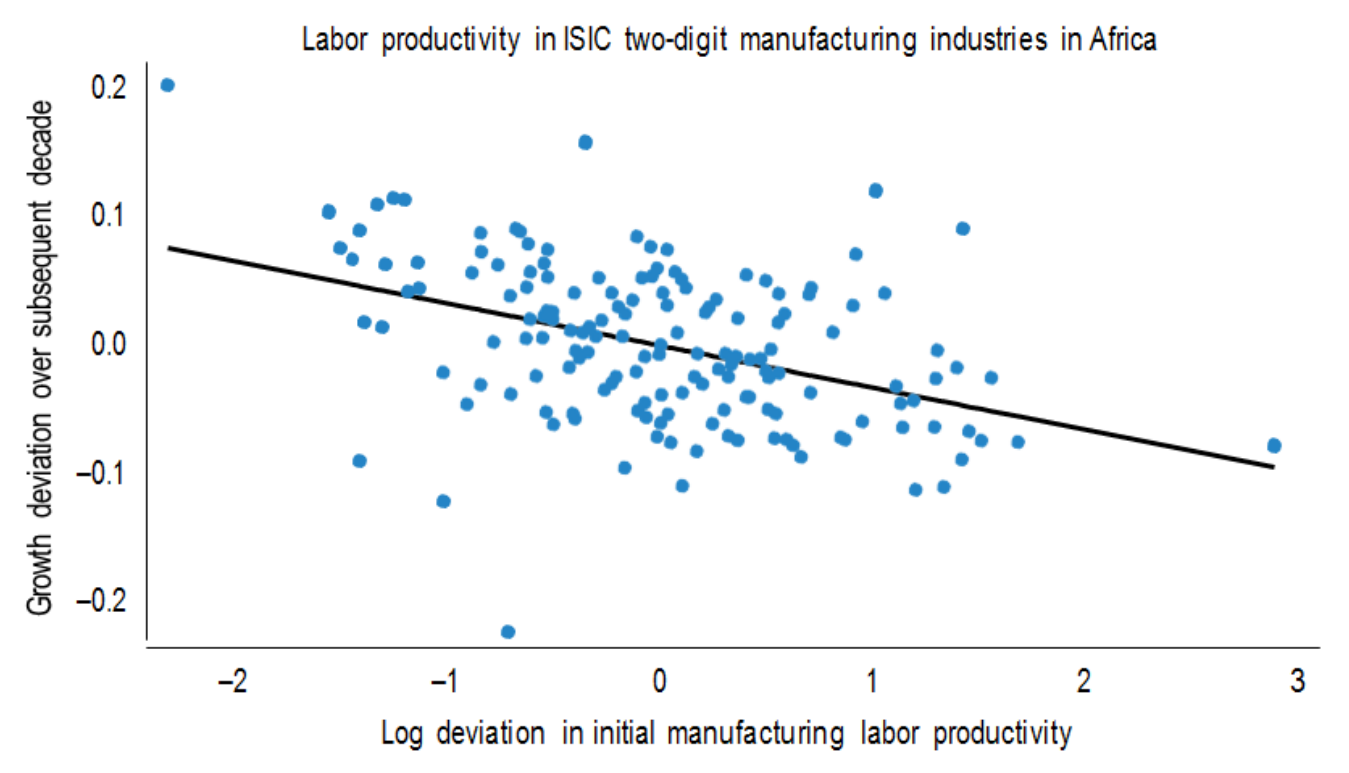

Source: Author's calculations, based on Rodrik (2013b).

Note: Data cover the 21 countries south of the Sahara (including Ghana) with the requisite data. Each observation represents an International Standard Industrial classification (ISIc) two-digit manufacturing industry inanAfrican country, for the latest 10-year period for which data are available. Period, industry, and period $x$ industry dummies are included as controls, so that values onthe axes are purged of these "fixed effects," butthere are nocountry-level controls.

\section{Prospects for Economic Convergence}

Against this backdrop, where should developing countries be focusing their energies to jumpstart economic convergence? The possible paths include reviving industrialization, focusing on natural resources and nontraditional agricultural products, and raising productivity in services.

\section{Revive Industrialization?}

The classic path of rapid catch-up through industrialization played out well in East Asia, as well as in Latin America and certain other countries, such as Turkey, during their earlier, importsubstituting phase. But there are a variety of reasons to think this path will figure much less prominently in the future: 
- Many African countries are starting out with a much better endowment of natural resources and are not as well positioned for specialization in manufacturing.

- The success of East Asian economies - China and its successors, such as Vietnam and Cambodia_poses significant competitive challenges to newcomers in manufacturing, especially in light of globalization and the reduced barriers to trade virtually everywhere.

- New trade rules - local content requirements, subsidies, import restrictions - limit to a much greater extent than previously the room for industrial policies, which Asian countries have deployed with some success.

- The economic difficulties of the advanced countries make them more resistant to significant surges of manufactured imports from low-cost sources.

- Technological changes in manufacturing itself have made the sector much more capital and skill intensive than in the past, reducing both the advantage of poor economies in manufacturing and the scope for labor absorption into the sector.

- The prospect of climate change and the greater awareness of the associated risks call for green technologies that are more environmentally friendly but also are more costly for developing nations.

Nevertheless, one can deploy counterarguments. First, diversification into manufacturing can sometimes be facilitated by the presence of natural resources; Ethiopia, for example, can deploy its high-quality livestock to turn itself into an exporter of designer shoes. Second, Chinese manufacturers are now looking for low-cost suppliers themselves, not the least in Africa. Third, even if the world economy stagnates, there are sizable domestic (Nigeria) and regional markets in Africa. There are glimmers of hope in all of these directions in the data-but they remain glimmers for the time being.

It is also true, as Baldwin (2011) has emphasized, that the spread of global supply chainswhat he calls "globalization's second unbundling" — has facilitated the spread of industry from the advanced countries to the periphery. 
New entrants do not have to build entire supply chains (from intermediate inputs to final products) at home; they can simply join existing global supply chains by producing a narrow range of components. Even so, industrialization remains limited and fleeting, even when a country can succeed in plugging into global supply chains.

Taken together, these trends imply that even the most successful countries of the future are likely to fall far short of the industrialization levels that have been the norm in economic history. The available data indicate that deindustrialization is now beginning to happen at lower levels of income. Manufacturing's share of employment peaked at above 30 percent in the United Kingdom and Germany, and at around 25 percent in Japan and South Korea. But in China, manufacturing employment rose to slightly less than 15 percent in the mid-1990s before it started to fall gradually. Vietnam, Cambodia, and other smaller countries will likely not surpass such levels. The apparent failure of African countries to industrialize to date and the deindustrialization of Latin America have to be seen against such a global context. The industrialization-led growth model may have run its course. The question is, what will take its place?

\section{Focus on Natural Resources and Nontraditional Agriculture?}

Natural resource booms can fuel growth, but resource sectors that exhibit high labor productivity — such as oil and diamonds — tend to be capital intensive and absorb few workers. Continued growth in a resource-based economy is dependent on rapid and sustained productivity increases in the resource sector, new discoveries, or a steady rise in world market prices. And even if one or more of these fortuitous circumstances materialize, the pat- tern of growth tends to become skewed. Growth benefits the state or a rentier class, spawns inequality and distributive politics, and proves generally detrimental to institutional development. Resource-based growth tends to produce spurts of growth, followed by stagnation or decline. Take the case of Ghana, where manufacturing expanded little while investment and growth were concentrated in the resource sector - a trend that was exacerbated after the discovery of oil in 2008. Aside from oil, Ghana's main exports are gold, cocoa beans, timber products, and other natural resources. Vietnam, meanwhile, is a major exporter of textiles and garments. In 2012, manufacturing's share of merchandise exports stood at 65 percent in Vietnam, but only 9 percent in Ghana (having actually come down from a peak of 25 percent in 2009). 
As for nontraditional agricultural products - horticulture, aquaculture, floriculture, and so on - they could well act as an intermediate stepping stone out of traditional farm products, but here, too, the record with labor absorption is not encouraging. We do not have any examples of countries that have successfully developed through diversification in agriculture. Typically, agricultural transformation represents the early stage of a growth takeoff. If not followed by rapid industrialization, growth peters out.

Moreover, given the inexorable trends in urbanization, the bulk of the new jobs has to be created in urban rather than rural areas. So it is hard to think of an agriculture-led path as anything other than a bridge to a more sustain- able urban-based strategy.

\section{Raise Productivity in Services?}

Tradable services can substitute to some extent for manufacturing, but the evidence to date on that has not been encouraging either. The reality is that an expansion of services is not necessarily a bad thing for structural transformation and growth, as long as the economy has been able to build up human capital and accumulate fundamental capabilities that transform those services into high-productivity activities (like finance and business services). However, this typically happens rather late in the development process, after industrialization runs its course, and high-productivity (tradable) segments of services cannot absorb as much labor. As for labor-intensive tradable services (like tourism), they have typically spawned few links to the rest of the economy and have not produced much diversification.

One prominent exception is the success of Hong Kong. Its structural transformation picture looks just like that in Vietnam, except that the roles of agriculture and manufacturing are reversed (Figure O.10). In Hong Kong, it is manufacturing that has rapidly shrunk since 1990, releasing more than 20 percent of the economy's labor force to other sectors. The displaced labor found employment in services (wholesale and retail trade, finance, insurance and business services, and so on), but at even higher levels of productivity. So deindustrialization was growth promoting. The difference with other countries is that Hong Kong first achieved significant levels of industrialization 


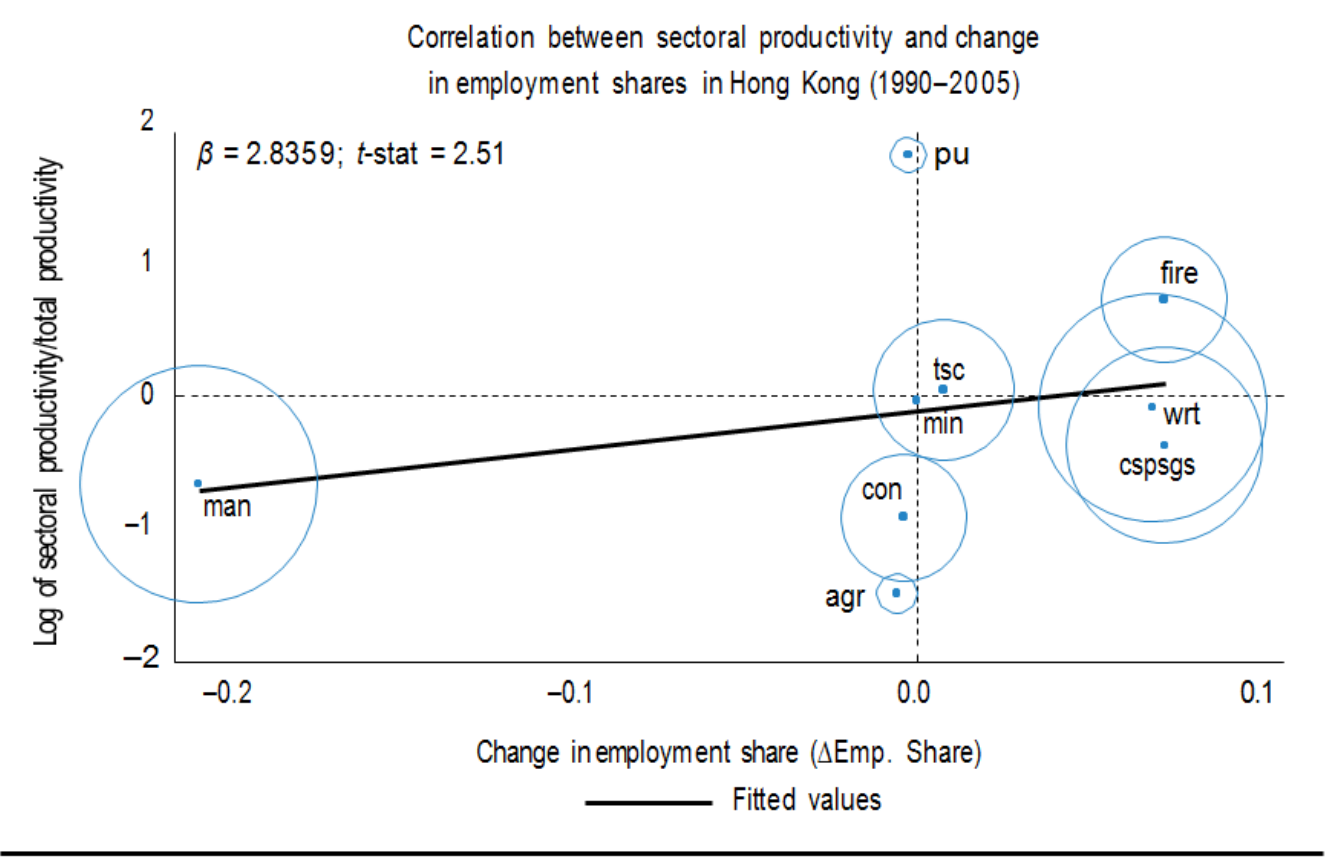

Source: Author's calculations with data from Timmer and de Vries (2009); Mcmillan and Rodrik (2011).

Note: Size of circles represents employment share in 1990; $\beta$ denotes coefficient of independent variable in regression equation: $\ln (p / P=\alpha+\beta \Delta \mathrm{Emp}$. Share; agr= agriculture; cspsgs = community, social, personal services, and government services; fire = finance, insurance, real estate, and business services; con = construction; $\operatorname{man}=$ manufacturing; $\min =$ mining and quarrying; $\mathrm{pu}=$ public utilities (electricity, gas, and water); tsc = transport, storage, and communications; wrt $=$ wholesale and retail trade.

before deindustrializing - and then used the intervening period to strengthen its human capital base and other fundamental capabilities.

In principle, then, structural transformation can play a potent positive role both during the early stages of development when there is "excess supply of labor" in agriculture and informal economic activities, and during later stages when capabilities have accumulated and modern services have caught up with and surpassed industrial activities. But neither outcome is ensured. Structural change is frequently slow, and often goes in the wrong direction. And the correspondence between market liberalization and structural change is weak, at best.

\section{Tempering Expectations}

All of this suggests that we should not be surprised if broad patterns of inter- sectoral structural change play a more muted role in the future. Development will have to happen the hard way for the most part, through the steady accumulation of skills and human capital and improvements in governance and institutions. In terms of the central growth-decomposition 
equation used in McMillan and Rodrik (2011) and the chapters that follow, growth will come mainly from the within-sector components of productivity change, rather than from structural change (Box O.2).

A corollary is that rapid growth of the type experienced in South Korea, Taiwan, China, China, Vietnam, and other East Asian cases will be out of reach for most developing countries. It has proved significantly more complicated and time consuming to upgrade a country's health system, tertiary education, or judiciary — to name just a few examples of nontradable sectors - to first- world standards than to ride the wave of global competitiveness in a narrow, but expanding, range of standardized manufacturing industries. Automatic escalators may be rare in nonmanufacturing parts of the economy.

One reason is that improving human capital and institutions entails a wide range of reforms and investments that are highly context specific and complementary to each other. Context specificity implies that off-the-shelf imported blueprints are not useful. Local experimentation and expertise are needed to get systems to cohere and work well. Complementarity means investments on a broad front are required for any of them to pay off. Together, these imply an Sshaped relationship between fundamentals and growth - investments in human capital and institutions produce at best moderate growth until they (and income) accumulate and reach a certain threshold (Rodrik 2013a). The downside of this mode of growth is that it can easily produce reform fatigue. 


\section{Box 0.2 Putting the focus on the "fundamentals"}

In all of our country studies, a frequent refrain is the need to improve "within- sector" productivity. Here, we try to illustrate the range of policies needed with current examples from our sample countries. These policies can be grouped into four key areas.

Political economy. In Zambia, where structural change has not translated into economic transformation, a major problem has been a lack of macro-economic stability and persistent policy volatility-like currency swings and periodic trade bans on maize exports and wheat imports, which deter investment in agriculture and other sectors. In Botswana, some of the constraints are as much political economy as technical ones. Building

up the industrial sector involves issues of political capture, and making more land available for business touches on issues of land markets and even immigration.

Labor regulations. In India, labor regulations appear to be a major impediment to employment growth in manufacturing. But in a democratic countrysuch as India, changing these laws may take a long time - which is worrisome, given that the future potential of agriculture and services in generating overall growth is limited (beyond a point) at India's stage in the development process.

Institutions and education. In Vietnam, which continues to feature large productivity gaps within and across sectors, it is vital to remove distortions (like improving access to land and capital) to help workers transition out of agriculture and to further enhance agricultural productivity. In Brazil, policies that raise overall labor productivity-like improving educational quality - are likely to have a deeper impact on growth than those that are strictly con- cerned with deepening an unfinished structural change.

Infrastructure. In Nigeria, the employment share in low-productivity agriculture is still quite high, indicating a potential for rapid structural change. But the country's levels of human capital and infrastructure are still abysmal, making a rapid exodus out of agriculture unlikely in the near future. In Ghana, which needs to diversify away from natural resource exports, a key focus is making the manufacturing sector more competitive. High nonlabor costs could be reduced by investing in roads, the power supply, and the regulatory framework. Although the business environment has improved greatly over the past 20 years, a lot remains to be done for Ghana to be as competitive as Mauritius or South Africa.

Source: Authors. 
Growth payoffs will appear as disappointing, despite substantial efforts at reform.

The bottom line is that the balance of forces going forward appears less favorable to rapid structural change than has been the case during the past six decades. We may well need to moderate the optimism that the recent experience of high growth across the developing world has spawned.

\section{References}

Acemoglu, D., S. Johnson, and J. Robinson. 2001. "The Colonial Origins of Comparative Development: An Empirical Investigation.” American Economic Review 91 (5): 1369-1401.

Aghion, P., and P. Howitt. 1992. "A Model of Growth through Creative Destruction."

Econometrica 60 (2): 323-351.

Androe, G. 1981. Industry in Ghana. Production Form and Spatial Structure. Stockholm: Sweden: Scandinavian Institute of African Studies.

Baldwin, R. 2011. Trade and Industrialisation after Globalisation's 2nd Unbundling: How Building and Joining a Supply Chain Are Different and Why It Matters. Working Paper 17716. Cambridge, MA: National Bureau of Economic Research.

Devarajan, S. 2013. "Africa's Statistical Tragedy." The Review of Income and Wealth 59 (S1): S9-S15. de Vries, G. J., M. P. Timmer, and K. de Vries. 2015. "Structural Transformation in Africa: Static Gains, Dynamic Losses.” Journal of Development Studies 51 (6): 674-688.

Diamond, J. 1997. Guns, Germs, and Steel: The Fates of Human Societies. New York: Norton. Ewusi, Kodwo. 1986. Statistical Tables on the Economy of Ghana 1950-1985. Accra: Institute of Statistical, Social and Economic Research, University of Ghana.

Field, A. J. 1978. "Sectoral Shift in Antebellum Massachusetts: A Reconsideration." Explorations in Economic History 15 (2): 146-171.

Foster, L., J. C. Haltiwanger, and C. J. Krizan. 2001. "Aggregate Productivity Growth. Lessons from Microeconomic Evidence.” In New Developments in Productivity Analysis, edited by C. R. Hulten, E. R. Dean, and M. J. Harper. Chicago: University of Chicago Press.

Glaeser, E. L., R. La Porta, F. Lopez-de-Silanes, and A. Shleifer. 2004. "Do Institutions Cause Growth?" Journal of Economic Growth 9 (3): 271-303. 
Gollin, D., D. Lagakos, and Michael E. Waugh. 2014. "The Agricultural Productivity Gap. "Quarterly Journal of Economics 129 (2): 939-993.

Grossman, G., and E. Helpman. 1991. Innovation and Growth in the Global Economy. Cambridge, MA: MIT Press.

GSS (Ghana Statistical Service). Various years. Population and Housing Censuses 1960, 1970, 1984, 2000, and 2010. Accra.

Gwartney, J., R. Lawson, and J. Hall. 2012. Economic Freedom of the World: 2012 Report. With contributions from S. L. Baier, C. Bjørnskov, M. Clance, A. M. Crisp, A. Dreher, G. P. Dwyer,N. J. Foss, and K. Gehring. Vancouver, BC: Fraser Institute.

Haggblade, S., P. B. R. Hazell, and T. Reardon. 2007. Transforming the Rural Nonfarm Economy. Baltimore: Johns Hopkins University Press.

Haltiwanger, J. 1997. "Measuring and Analyzing Aggregate Fluctuations: The Importance of Building from Microeconomic Evidence." Federal Reserve Bank of St. Louis Review 79 (3): $55-78$.

Herrendorf, B., R. Rogerson, and A. Valentinyi. 2013. Growth and Structural Transformation. Working Paper 18996. Cambridge, MA: National Bureau of Economic Research.

Jerven, M., and D. Johnston. 2015. Statistical Tragedy in Africa? Evaluating the Data Base for African Economic Development. London: Routledge.

Johnston, B. F., and P. Kilby. 1975. Agriculture and Structural Transformation: Economic Strategies in Late-Developing Countries. New York: Oxford University Press.

Johnston, B., and J. Mellor. 1961. "The Role of Agriculture in Economic Development." American Economic Review 51 (4): 566-593.

Lewis, W. A. 1954. "Economic Development with Unlimited Supplies of Labor." Manchester School of Economic and Social Studies 22 (2): 139-191.

Matsuyama, K. 1992. "Agricultural Productivity, Comparative Advantage, and Economic Growth.” Journal of Economic Theory 58 (2): 317-334.

McMillan, M. 2013. “The Changing Structure of African Economies.” Unpublished paper. 
McMillan, M., and K. Harttgen. 2014. What Is Driving the Africa Growth Miracle? Working Paper 20077. Cambridge, MA: National Bureau of Economic Research.

McMillan, M., and D. Rodrik. 2011. "Globalization, Structural Change, and Productivity Growth.” In Making Globalization Socially Sustainable. Geneva: International Labour Organization and World Trade Organization.

Mokyr, J. 1976. Industrialization in the Low Countries, 1795-1850. New Haven: Yale University Press.

Mundlak, Y., R. Butzer, and D. F. Larson. 2012. "Heterogeneous Technology and Panel Data: The Case of the Agricultural Production Function." Journal of Development Economics 99 (1): 139-149.

Murphy, K., A. Shleifer, and R. Vishny. 1989. "Industrialization and the Big Push.”' Journal of Political Economy 97 (5): 1003-1026.

Ranis, G., and J. C. Fei. 1961. "A Theory of Economic Development.” American Economic Review 51 (4): 533-558.

Rodrik, D. 2013a. The Past, Present, and Future of Economic Growth. GCF Working Paper 1. London: Global Citizen Foundation. www.sss.ias.edu/files/pdfs/Rodrik/Research/GCF Rodrik-working-paper-1_-6-24-13.pdf.

- 2013b. "Unconditional Convergence in Manufacturing." Quarterly Journal of Economics 128 (1): 165-204.

Schultz. T. W. 1953. The Economic Organization of Agriculture. New York: McGrawHill. Singal, M. S., and J. D. M. Nartey. 1971. Sources and Methods of Estimation of National Income at Current Prices in Ghana. Accra: Central Board of Statistics.

Solow, R. M. 1956. “A Contribution to the Theory of Economic Growth.” Quarterly Journal of Economics 70 (1): 65-94.

Timmer, M. P., and G. J. de Vries, 2009. "Structural Change and Growth Accelerations in Asia andLatin America: A New Sectoral Data Set," Cliometrica 3 (2): 165-190.

World Bank. Various years. Doing Business database. Washington, DC. www.doingbusiness.org/. 
World Bank. Various years. World Development Indicators database. Washington, DC. Accessed December 2015. http://data.worldbank.org/data-catalog/world-development-indicators.

Wright, G. 1979. "Cheap Labor and Southern Textiles before 1880.” The Journal of Economic History 39 (3): 655-680. 